\title{
Seismotectonic modeling of the repeating $M$ 7-class disastrous Odawara earthquake in the Izu collision zone, central Japan
}

\author{
Katsuhiko Ishibashi \\ Research Center for Urban Safety and Security/Department of Earth and Planetary Sciences, Kobe University, Kobe 657-8501, Japan
}

(Received February 16, 2004; Revised July 15, 2004; Accepted July 21, 2004)

\begin{abstract}
Odawara City in central Japan, in the northernmost margin of the Philippine Sea (PHS) plate, suffered from severe earthquake disasters five times during the last 400 years with a mean repeat time of 73 years; in 1633, 1703, 1782, 1853 and 1923. In this region, non-volcanic Izu outer arc (IOA), the easternmost part of the PHS plate, has been subducted beneath Honshu (Japanese main island), and volcanic Izu inner arc (IIA) on the west of IOA has made multiple collision against Honshu. I hypothesize 'West-Sagami-Bay Fracture' (WSBF) beneath Odawara, a north-south striking tear fault within the PHS plate that has separated the descending IOA crust from the buoyant IIA crust, through examinations of multiple collision process and the PHS plate configuration. WSBF is considered a blind causative fault of the 1633, 1782 and $1853 M 7$ Odawara earthquakes, and is inferred to have ruptured also during the 1703 and 1923 great Kanto earthquakes simultaneously with the interplate main fault. A presumable asperity on WSBF just beneath Odawara seems to control the temporal regularity of earthquake occurrence. Though WSBF has not yet been detected directly, it is considered an essential tectonic element in this region, which might be a fracture zone with a few or several kilometer thickness actually. The WSBF hypothesis is the only conceptual model to explain the earthquake recurrence beneath Odawara.
\end{abstract}

Key words: Odawara earthquake, repeating earthquake, West-Sagami-Bay Fracture, South Fossa Magna, earthquake prediction, seismotectonics, collision zone.

\section{Introduction}

Odawara City on the northwestern coast of Sagami Bay, the Pacific coast of central Honshu (the Japanese main island) (Fig. 1), suffered from severe earthquake disaster five times since the 17 th century with a constant interval of about 73 years; in 1633, 1703, 1782, 1853 and 1923. Odawara was one of the important vanguard castle towns in the Kanto district (Tokyo Metropolitan area and its surroundings) for the military government in Edo (present Tokyo; Fig. 1(b)) in the Edo period (1603-1867), and has been the central city in the western part of Kanagawa-ken (Kanagawa Prefecture; see Fig. 7(a)) since the Meiji Restoration of 1868 (now, nearly 200,000 population). Before the 16th century the seismicity around Odawara is obscure because of the lack of historical records.

The 'Odawara earthquake,' which has been a popular name since the Edo period, is considered an important and interesting target of earthquake prediction research. In general, seismotectonic modeling of, or understanding the tectonic significance of, a remarkable seismic activity including a future earthquake is very important, as a target setting, for physical short-term earthquake prediction research (Ishibashi, 1982) as is the case of the hypothetical Tokai, Japan, earthquake (e.g., Ishibashi, 1981a). The study of Odawara earthquake, however, has not been so active because the area in question is tectonically very complicated.

Copy right (C) The Society of Geomagnetism and Earth, Planetary and Space Sciences (SGEPSS); The Seismological Society of Japan; The Volcanological Society of Japan; The Geodetic Society of Japan; The Japanese Society for Planetary Sciences; TERRAPUB.
The Odawara area is among the northernmost boundary of the Philippine Sea (PHS) plate (Fig. 1). To the west of Odawara, the Izu Peninsula, the northern tip of the PHS plate, is colliding against Honshu because of its buoyancy, and to the southeast of Odawara, the PHS plate is being subducted beneath Honshu at the Sagami trough bringing about $M$ 8-class interplate earthquakes such as the 1703 and 1923 great Kanto earthquakes (K in Fig. 1(b)). Odawara suffered the heaviest damage among disaster areas by these two earthquakes. The 1633, 1782 and 1853 disasters were caused by $M 7$-class earthquakes around Odawara.

Despite the remarkably constant repeat time of the five disasters at Odawara due to earthquakes, there has been little interest in modeling the earthquake recurrence in this area, the regular sufferings being regarded as accidental. Main reasons for this view are: $M$ 7-class local earthquakes and $M$ 8-class regional earthquakes are mixed, and no causative fault of the $M 7$-class local events has been known.

The region along the northern boundry of the PHS plate, i.e., the Izu collision zone and its surroundings, is called the South Fossa Magna (SFM) (stippled area in Fig. 1(a)). The pre-Miocene geologic terranes surrounding SFM (Am and $\mathrm{Km}$ in Fig. 1(b)) bends sharply to form a cusp, and the Neogene to Quaternary terranes in SFM undergo strong compressive deformation (e.g., Matsuda, 1978). For five-year period from 1985 to 1989 a research project entitled 'Collision tectonics in the South Fossa Magna' was carried out as a part of the Japanese national program (DELP; Dynamics and Evolution of the Lithosphere Project) for the International Lithosphere Project (ILP) (e.g., Niitsuma, 1989, 1999). In this 


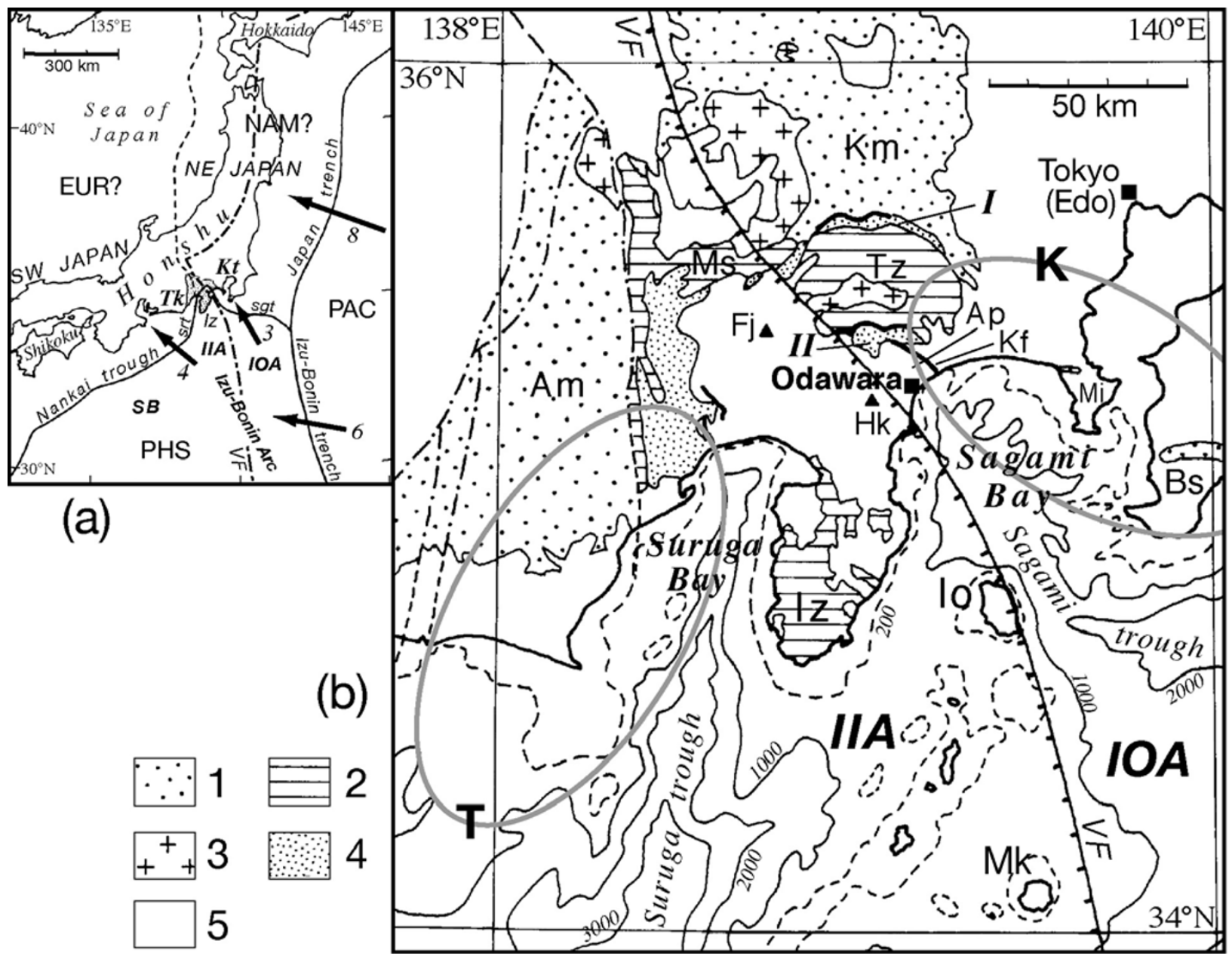

Fig. 1. (a) Plate tectonic setting of the Izu collision zone, or the South Fossa Magna (SFM; stippled area). EUR, Eurasian plate; NAM, North American plate; PAC, Pacific plate; PHS, Philippine Sea plate. Subduction boundaries of PAC and PHS are shown by solid lines; Sgt, Sagami trough; Srt, Suruga trough. Arrows and italic numerals (in $\mathrm{cm} / \mathrm{yr}$ ) roughly indicate the relative plate motions at each boundary (Seno et al., 1993, 1996). The boundary between the two continental plates (broken line) remains controversial. Iz, Izu Peninsula; Kt, Kanto district; Tk, Tokai district; IIA, Izu Inner Arc; IOA, Izu Outer Arc; $S B$, Shikoku Basin. The chain line $(V F)$ in northeast Japan and the Izu-Bonin arc is the volcanic front associated with the subduction of PAC. (b) Close-up of SFM (east side of Am and south side of $\mathrm{Km}$ ) including Odawara. Two large ellipses with $\mathrm{K}$ and $\mathrm{T}$ roughly represent the source regions of great interplate Kanto and Tokai earthquakes, respectively. $I$ and $I I$ indicate paleo-trough I and paleo-trough II, respectively. The line $V F$ is the volcanic front. Water depths are in meters. Am, Akaishi Mountains; Ap, Ashigara Plain; Bs, Boso Peninsula; Fj, Mt. Fuji; Hk, Hakone volcano; Io, Izu-Oshima Island; Iz, Izu Peninsula; Kf, Kozu-Matsuda fault; Km, Kanto Mountains; Mi, Miura Peninsula; Mk, Miyake Island; Ms, Misaka Mountains; Tz, Tanzawa Mountains. 1, pre-Neogene basement rocks; 2, Miocene pyroclastics; 3, Neogene intrusives; 4, late-Miocene to Pleistocene trough-fill sediments; 5, Pliocene and Quaternary (except for the west of Am, where pre-Neogene).

project various phenomena related to the multiple collision of the proto-Izu-Bonin arc in SFM were revealed by many geological and geophysical investigations. In order to elucidate causative faults of the $M$ 7-class Odawara earthquakes, full consideration of multiple collisions in time and collisionsubduction transition in space in SFM is indispensable.

Ishibashi $(1976,1977,1985)$ first paid attention to the Odawara earthquakes from the viewpoint of plate tectonics. He proposed a working hypothesis, through investigations of the 1923 Kanto earthquake, historical Odawara earthquakes and crustal movements around Odawara, that a NS-striking and westerly-dipping low-angle thrust within the PHS plate ('West-Sagami-Bay fault') had been developing south-off and beneath Odawara due to the long-term collision of the Izu Peninsula. He considered that not only earthquake disasters at Odawara but also large-scale seismic ruptures on this 'nascent subduction boundary' had recurred every ca. 70 years. In this modeling, however, little atten- tion was paid to the evolution of the PHS plate convergence. Ishibashi (1988b, c), then, taking into consideration the multiple collision process in SFM since the middle Miocene, revised the seismotectonic model of the Odawara earthquake. He changed the idea of West-Sagami-Bay fault to a concept of 'West-Sagami-Bay Fracture' (hereafter WSBF), a highangle tear fault within the PHS plate. As for the earthquake name, he also used 'Kanagawa-ken-seibu (Western Kanagawa Prefecture) earthquake.'

Various investigations to examine the WSBF hypothesis were carried out in the research project entitled 'Research on the prediction of $M$ 7-class inland earthquakes' under the Special Coordination Funds for Promoting Science and Technology during 1987-1991 (e.g., Hagiwara, 1993). The existence of WSBF, however, has not yet been proved nor denied. During the last decade, mostly after the drastic change in circumstances of earthquake research in Japan due to the 1995 Kobe earthquake, investigation and discussion on the 
Odawara earthquake have been depressed. Still, not a few Japanese seismologists are concerned about near-future occurrence of a large earthquake around Odawara, apart from its mechanism. And, it seems that the WSBF hypothesis is yet the only conceptual model of the earthquake recurrence in the Odawara area.

In this paper I summarize the discussions related to the WSBF hypothesis, which has been done mainly in the Japanese language, and present the latest interpretation. I will focus on a seismotectonic modeling rather than statistic or probabilistic discussions. It should be noted that clarifying the tectonophysical nature of the Odawara earthquake is also a key to understand the PHS plate convergence process in SFM, which is directly related to the true mechanism of the Tokai, Kanto and underneath-Tokyo earthquakes.

\section{Tectonic Setting of the Odawara Area}

The Japanese Islands are located in the midst of the plate convergence zone at the northwestern margin of the Pacific Ocean. Two oceanic plates, the Philippine Sea (PHS) and the Pacific (PAC), are converging with two continental plates (Fig. 1(a); e.g., Seno et al., 1993, 1996) (I do not touch on the issues of the two continental plates because they are controversial and not important in this paper).

The PAC plate is being subducted beneath both northeast Japan and the PHS plate west-northwestward at the Japan and Izu-Bonin trenches. Due to this subduction, the eastern margin of the PHS plate is an oceanic island arc, the IzuBonin volcanic arc (Fig. 1). A distinct volcanic front associated with the PAC plate subduction runs in the northeast Japan and Izu-Bonin arcs continuously and crosses the convergent boundary between the PHS plate and Honshu. This feature and its fundamental origin of the arc-arc collision are the most conspicuous points that make the study area very unique on the earth in terms of plate tectonics, and are considered the key to understand the Odawara earthquake.

The PHS plate on the south of Honshu can be divided into three parts from east to west (Fig. 1); non-volcanic Izu outer arc (IOA), volcanic Izu inner arc (IIA) and back-arc basin (Shikoku Basin; SB). The non-volcanic IOA is being subducted beneath the southern part of northeast Japan (Kanto district) at the Sagami trough, which runs northwestward into Sagami Bay from the off-Boso TTT-type triple junction. SB is being subducted beneath southwest Japan at the WSW-ENE running Nankai trough. This subduction boundary continues eastward to the Suruga trough, which runs almost north-south entering into Suruga Bay. The relative motions are north-northwestward and about $3 \mathrm{~cm} / \mathrm{yr}$ at the Sagami trough, and west-northwestward and 4 to $5 \mathrm{~cm} / \mathrm{yr}$ at the Suruga-Nankai trough (Seno et al., 1993). This difference in a narrow region is due to the east-west convergence between northeast and southwest Japan. The volcanic Izu inner arc (IIA) between IOA and SB is colliding against the Honshu arc to the north of the Izu Peninsula because of its buoyancy.

Odawara (Fig. 1(b)) is located just between the subduction boundary of IOA and the collision boundary of IIA, and very near to the vocanic front running along Mt. Fuji, Mt. Hakone, Izu-Oshima Island and Miyake Island.

The Sagami trough reaches the northwestern coast of
Sagami Bay. Its landward continuation is the Ashigara Plain on the east of Odawara (Fig. 1(b)). At the northeastern edge of the Ashigara Plain there exists a remarkable active fault, the Kozu-Matsuda fault, and its northeastern side, the Oiso Hills (see Fig. 4(a)), has been considerably uplifted. It has been widely accepted since Ando (1971) and Kanamori (1971) that on the plate interface northeasterly dipping from the Sagami trough, the seismic rupture of the 1923 Kanto earthquake of $M_{S} 8.2$, the last event that caused serious disaster to Odawara, took place.

On the west of Odawara, there is Hakone volcano on the north of the Izu Peninsula (see also Fig. 4(a)). Sugimura (1972) pointed out that the present northernmost surface boundary between the PHS plate and the land plate of Honshu runs along the northern foot of Hakone volcano connecting the Sagami trough and the Suruga trough. Since then, it has become a common view that the starting line of the PHS plate subduction beneath the Kanto district is the axis of the Sagami trough and the Ashigara Plain (see Fig. 2). Nakamura and Shimazaki (1981), Shimazaki et al. (1981) and Nakamura et al. (1984) delineated this line clearly, calling it 'plate material boundary,' which has solidified the common view.

In this plate tectonic framework the tectonic implication of the 1703 and 1923 Kanto earthquakes is basically clear. The tectonic meaning of $M 7$-class earthquakes around Odawara, on the contrary, has been very obscure. Are they smaller interplate events along the northernmost Sagami trough or the Kozu-Matsuda fault? Or, are they intraplate events within the PHS plate like large earthquakes in the Izu Peninsula or within the overriding land plate?

\section{Multiple Collision in the South Fossa Magna (SFM)}

There are two remarkable and essential tectonic features in SFM; one is mainly geological and superficial, and the other, seismological and deeply interior.

The first is that intermittently accreted masses of Miocene submarine volcanics and pyroclastics originating from the paleo-Izu volcanic arc (paleo-IIA) (Ms, Tz, Iz and others in Fig. 1(b)) and thickly piled late-Miocene to Pleistocene detritus filling paleo-troughs between them (I, II and others in Fig. 1(b)) have been strikingly compressed and uplifted. This means that considerable portion of the paleo-IIA crust has not been subducted into the asthenosphere beneath Honshu but remained on the surface. Amano $(1986,1991)$ and Takahashi $(1986,1989)$ proposed models of multiple collision in SFM since the middle Miocene, essentially similar to each other, based on investigations of surface geology and granitic magmatism, respectively.

The second noticeable feature is that, to the north to northwest of the Izu Peninsula, there exists a fan-shaped large gap of the seismic PHS slab, whereas beneath the Kanto and the Tokai districts the PHS slabs (the Kanto slab and the Tokai slab, respectively) are clearly seen. This feature is obvious in all plate configuration maps obtained in the 1980's and early 1990's based on seismicity data (e.g., Ishida, 1992; Fig. 2; for references and figures up to 1989, see Ishibashi and Ishida (1989), Okada (1990) and Ishida (1992)), and is also shown by the recent high-quality integrated hypocenter 


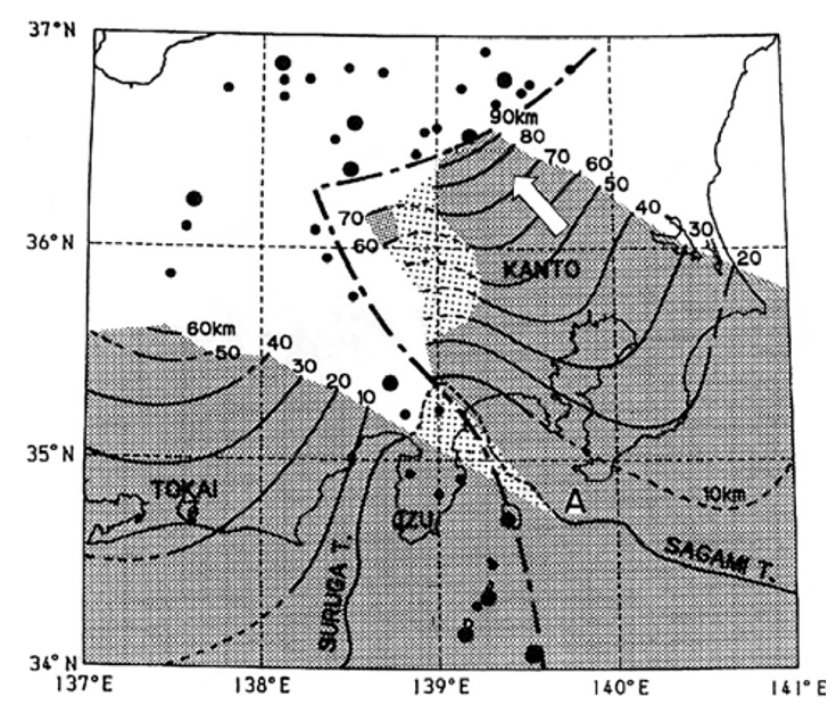

Fig. 2. Depth contour map of the upper surface of the subducted PHS plate proposed by Ishida (1992) (reproduced from figure 9 in the paper). The dashed lines and light-shaded zones denote uncertain results. The white arrow indicates the direction of the PHS plate motion relative to the EUR plate. The chain line and solid circles represent the volcanic front and major Quaternary volcanoes, respectively.

data of the Japan Meteorological Agency (see Figs. 11 and 12). In Fig. 12 the contrast is clear that a descending seismic slab cannot be seen to the north of the Izu Peninsula (N1 and N2) while it is traced as the Kanto slab in the east (N4 and N5). Many investigators suppose that the descending PHS slab itself does exist in this apparent gap, just being aseismic because of the relatively warm nature of the slab, which is partly intrinsic and partly due to the subduction of the PAC plate, otherwise the areal conservation of the lithospheric plate would be broken. Recently, Seno and Yamasaki (2003) suggested that the gap of slab seismicity was due to the lack of dehydration of the slab. Ishibashi (1986), on the contrary, interpreted that there was actually no descending slab to the north of the Izu Peninsula.

The Kanto slab is regarded as the subducted paleo-IOA lithosphere. Since it is traced northward continuously from the Sagami trough down to the depth around $90 \mathrm{~km}$ as long as more than $200 \mathrm{~km}$ (Fig. 2), the paleo-IOA lithosphere is inferred to have been subducted at the Sagami trough, without any jump of the surface boundary, throughout the entire period of subduction. The net duration of the subduction is estimated at $7 \sim 8$ million years, if we assume the same relative velocity as the present one, $3 \mathrm{~cm} / \mathrm{yr}$ (Seno et al., 1993), for the whole period.

These distinct facts in and around SFM strongly suggest that during the whole course of the PHS plate convergence with Honshu, two different modes of plate consumption, contrasting remarkably with each other, have been progressing in the central part of SFM and at the Sagami trough as follows: (1) Concerning the relatively warm and buoyant IIA crust, a few stages of buoyant subdution and underplating have been taking place, each of which was followed by collision and accretion of a larger submarine volcano or volcanic island, then by an interruption of relative motion and, on occasion, by a jump of subduction boundary; (2) The relatively
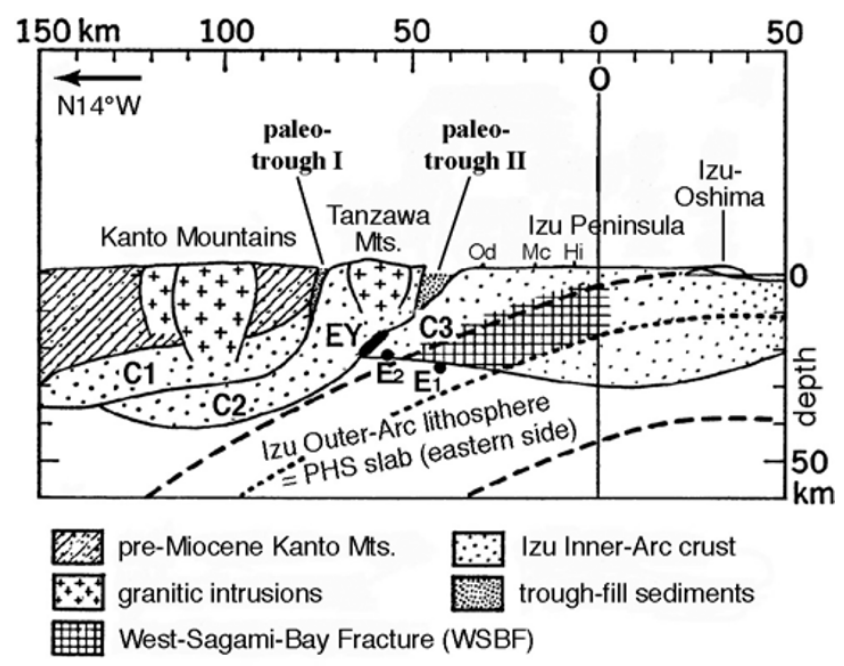

Od, Odawara; Mc, Manazuru Cape; Hi, Hatsu-shima Island

Fig. 3. Schematic underground structure in and around SFM inferred by the plate evolution model of Ishibashi (1986) (slightly modified from figure 2 in Ishibashi (1988b)). Cross sections of IIA and IOA projected to the lines A and B in Fig. 4(a), respectively, are overlapped. Vertical line $\mathrm{O}$ indicates the position of $35^{\circ} \mathrm{N}$ on line $\mathrm{B} . \mathrm{C} 1, \mathrm{C} 2$ and $\mathrm{C} 3$ represent underplated buoyant IIA crust. EY, eastern Yamanashi earthquakes; $\mathrm{E}_{1}$ and $E_{2}$, hypocenters of the 1923 Kanto earthquake and the 1929 earthquake, respectively (see Fig. 4).

cold and less buoyant IOA lithosphere has been subducted beneath the Kanto district at the fixed surface boundary, the Sagami trough, though its location may have moved to some extent, especially in its northwestern part. Since IIA and IOA are parts of the identical PHS plate, these two kinds of motion should have been taking place synchronously, and the IIA and IOA crusts should have been separated from each other somewhere around the western edge of the Sagami trough.

Detailed discussion on the Neogene to modern collision/subduction process in SFM and reconstruction of the plate motion will be made in another paper. Here, I just briefly summarize Ishibashi's (1986) model of synchronized evolution of multiple collision of IIA and subduction of IOA which developed Amano's (1986) and Takahashi's (1986) geological models (Fig. 3). Ishibashi (1986) assumed a $3 \mathrm{~cm} / \mathrm{yr}$ velocity and north-northwestward direction of the PHS plate motion relative to the Kanto district for the whole period, and considered that the IIA lithosphere consisted of buoyant crust only because of the PAC plate subduction, while the IOA lithosphere had crust and upper mantle.

Concerning the buoyant IIA crust, Figure 3 incorporates (see also Fig. 1) the underplating of $\mathrm{C} 1$ beneath the protoKanto Mountains at the paleo-trough I (ca. $12 \sim 10 \mathrm{Ma}$ ), its interruption due to the collision of the Misaka block (not shown in Fig. 3 because it is situated to the west of this profile), restarting of the underplating of $\mathrm{C} 2$ at the paleo-trough I (late Miocene) which caused remarkable uplift of the protoKanto Mountains, its interruption due to the collision of the Tanzawa block (ca. $6 \sim 5 \mathrm{Ma}$ ), jump of the boundary to the paleo-trough II on the south of the Tanzawa block, the buoyant subduction of C3 (since late Pliocene) and the collision of the Izu block (since ca. $1 \mathrm{Ma}$ ) which has caused enormous uplift of the Tanzawa Mountains. This model well explains 


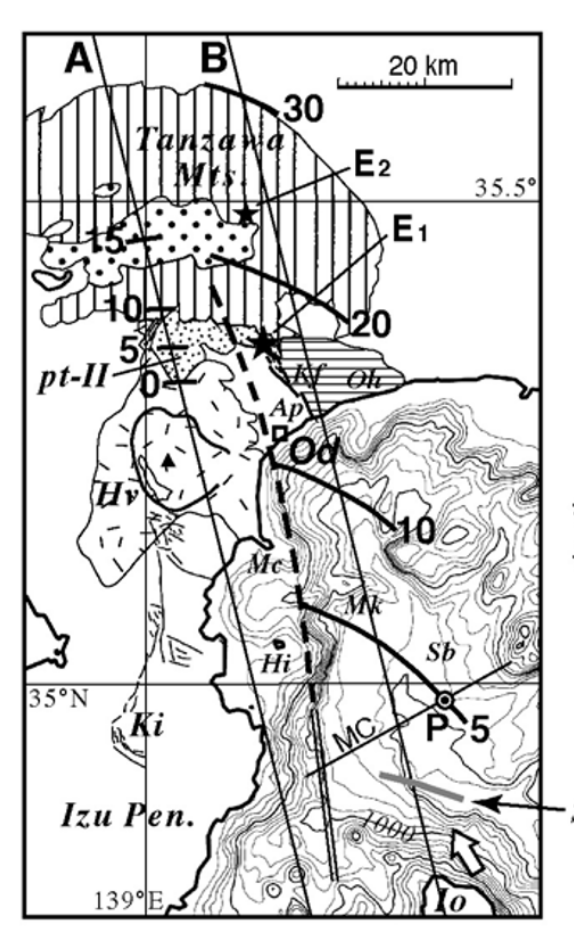

(a)

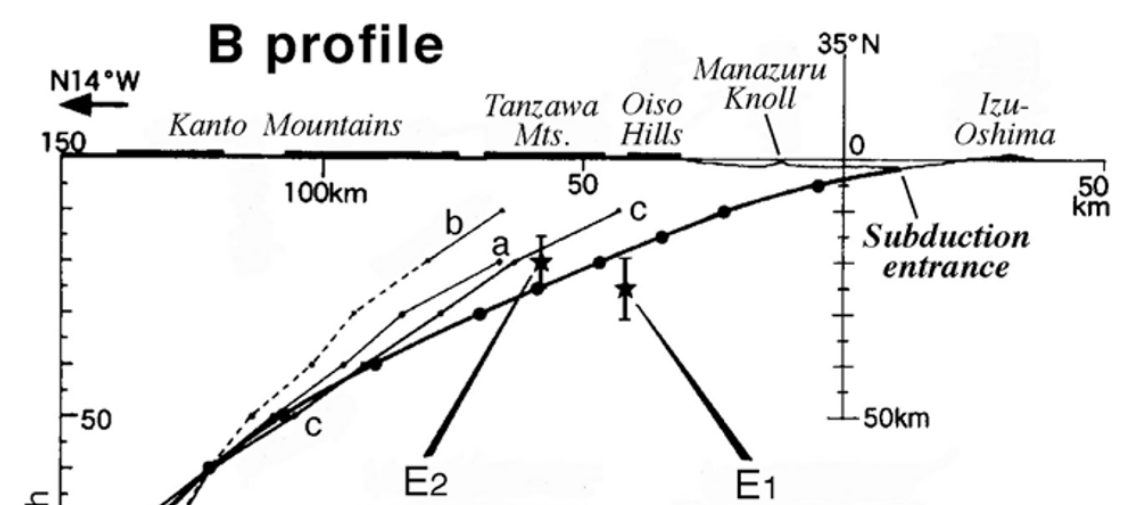

1929 July 27, M6.3

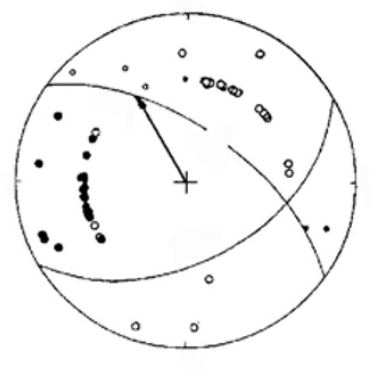

1923 Sept. 1, M7.9

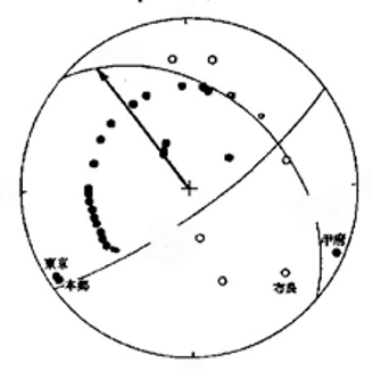

(b)

Fig. 4. (a) Inferred depths of the upper surface of the subducted PHS plate in and to the north of the western Sagami Bay region (thickest solid lines; numerals are in km) (modified from figures in Ishibashi (1988c, 1999)). Thick broken line is the surface projection of the upper edge of the hypothesized West-Sagami-Bay Fracture (WSBF). Double line on the south of WSBF shows the fault plane of the 1980 East-off-Izu-Peninsula earthquake ( $M$ 6.7; e.g., Takeo, 1988). White arrow on the north of Izu-Oshima Island (Io) indicates the direction of the PHS plate motion relative to the Kanto district. Line MC and point $\mathrm{P}$ in Sagami Bay represent the multi-channel seismic reflection survey line and the $5 \mathrm{~km}$-deep reflection point, respectively, after Kato et al. (1983). $\mathrm{E}_{1}$ and $\mathrm{E}_{2}$ are epicenters of the 1923 great Kanto earthquake (Hamada, 1987) and its large aftershock in 1929 (Ishibashi, 1981b), respectively. Isobaths are every 100 meters (1000 meter is indicated). Ap, Ashigara Plain; $H i$, Hatsu-shima Island; $H v$, caldera rim of Hakone volcano; $K i$, Kita-Izu active fault system; $K f$, Kozu-Matsuda fault; $M c$, Manazuru Cape; $M k$, Manazuru Knoll; $O d$, Odawara; $O h$, Oiso Hills; $S b$, Sagami Basin. pt-II is paleo-trough II. (b) Vertical cross section along line B in (a) for estimating the upper surface of the subducted IOA lithosphere. Lines a (solid in the deeper part), b (broken in the deeper part) and c show upper surfaces of the PHS slab estimated by Noguchi (1985), Ishida (1986) and Ishida (1992), respectively. $E_{1}$ and $E_{2}$ in (a) are also projected with error bars of depth calculation. Fault-plane solutions of $E_{1}$ and $E_{2}$ (equal-area projections of lower focal hemisphere) are after Ishibashi (1981b). For details see text.

the fact that the crust around the Kanto Mountains is now extraordinarily thick in Japan, as thick as about $40 \mathrm{~km}$ (Furumoto et al., 1989). Figure 3 also illustrates the subducted IOA lithosphere to the east.

Kaizuka (1984), from the viewpoint of geomorphology, examined the tectonic processes of growth of landforms in and around SFM and pointed out the importance of the differential motion between IOA and IIA by assuming a short transform fault, which was a scissor-fault-type with a larger vertical displacement toward the north, along the volcanic front where the crust was considered relatively weak. Ishibashi $(1986,1988 b$, c) concluded that the place where the buoyant IIA crust and the descending IOA crust had been separated from each other was the scissor fault hypothesized by Kaizuka (1984), and considered that it was still functioning at present in the west part of Sagami Bay, northeast off the Izu block. In the next section we will examine the current geometry of the PHS plate in this area in detail.

\section{3-D Geometry of the PHS Plate and the West- Sagami-Bay Fracture (WSBF)}

Concerning the geometry of the subducted PHS plate in SFM or in the Kanto-Tokai district, including the surface plate boundary, Ishida's (1992) isodepth contour map for the plate upper surface inferred by hypocenter distribution, velocity structure and fault-plane solutions (Fig. 2) has been widely referred to, whereas there are many other depth contour maps proposed in the 1980's in the same manner, as mentioned in the previous section.

A remarkable point in these maps is that depth contours are considerably different from map to map especially in the shallower part (see Fig. 4(b)). This implies that estimated depths of the upper surface of a subducted oceanic plate in the shallower part than 30 or $40 \mathrm{~km}$ are not necessarily objective no matter how accurate hypocentral data are; in general, it is difficult in the shallower part to distinguish earthquakes occurring within a subducted plate from events in the overriding plate, and in every map a surface plate boundary is assumed as a basic constraint of the plate configuration.

Ishida (1992) also made an assumption that the subduction of the PHS plate began at the Sagami and Suruga troughs (almost the same as the plate material boundary delineated by Nakamura et al. (1984) judging from Fig. 2). She also assumed that the slab shape was more or less continuous. However, whether these two assumptions are appropriate or not is a fundamental problem in the particular place around Sagami Bay. Here, it should be noted that the plate material boundary drawn by Nakamura and Shimazaki (1981), Shi- 
mazaki et al. (1981) and Nakamura et al. (1984) involved significant self-contradiction in the west part of Sagami Bay; though they approved the West-Sagami-Bay fault as a tear fault of the PHS plate, they did not incorporate its meaning and geometry into the location of the plate material bondary.

Ishibashi (1988b,c, 1999) emphasized the importance of the position where an oceanic plate starts to be subducted beneath the overriding plate (subduction entrance), which was also discussed by Koyama (1995), and re-examined the location of the subduction entrance and the depth of the upper surface of the PHS plate in and to the north of the western Sagami Bay region as follows (Fig. 4).

First, two profiling lines have been taken; line $\mathrm{A}$ in the IIA side and line B in the IOA side (Fig. 4(a)). B is a line with a strike of $\mathrm{N} 14^{\circ} \mathrm{W}$ connecting the northern tip of IzuOshima Island and the point of $36^{\circ} \mathrm{N} / 139^{\circ} \mathrm{E}$. There is no special meaning for these particular points, but the line has been drawn near the western edge of the Kanto slab in the direction roughly parallel to the edge. A is a line parallel to $\mathrm{B}$ and $15 \mathrm{~km}$ apart from it.

\subsection{IOA lithosphere}

Along B, special attention has been paid to the submarine topography of the Sagami Basin in Sagami Bay, the hypocentral location of the 1923 great interplate Kanto earthquake recalculated by Hamada (1987), and the PHS slab upper surface deeper than $50 \mathrm{~km}$ estimated by Noguchi (1985) and Ishida $(1986,1992)$. By smoothly connecting the topographic profile from Izu-Oshima to the Sagami Basin, the projection of the 1923 hypocenter to line B, and the slab upper surface in the deeper part, the upper surface of the PHS plate (IOA lithosphere) along line B has been inferred as the thick solid line in Fig 4(b). Here, the recalculated hypocenter of a $M 6.3$ earthquake in 1929 which is considered an interplate event from its fault-plane solution (Ishibashi, 1981b) has also been used. Some of the isodepth contours of Ishida (1986, 1992), which do not cover line B, have been extrapolated to the line B (broken part in Fig. 4(b)). The slab upper surfaces in the shallower part than $40 \mathrm{~km}$ estimated by Noguchi (1985) and Ishida $(1986,1992)$ have been ignored because they appear unreliable reflecting the situation explained above. On the contrary, slab upper surfaces in the deeper part estimated by them coincide one another well.

Then, the depths have been read on the thick solid line in Fig. 4(b) every $5 \mathrm{~km}$ for the shallower part than $30 \mathrm{~km}$ and every $10 \mathrm{~km}$ for the deeper part. On the other hand, the point $\mathrm{P}$ in Fig. 4(a), where the basement forming the Izu Peninsula was recognized at the depth of $5 \mathrm{~km}$ by a multichannel seismic reflection survey along the line MC in the figure (Kato et al., 1983), has been regarded to represent the upper surface of the PHS plate. P and the point of $5 \mathrm{~km}$ deep on line B have been connected smoothly and the contour line for the depth of $5 \mathrm{~km}$ has been obtained as shown in Fig. 4(a). Depth contour lines for $10 \mathrm{~km}, 20 \mathrm{~km}$ and $30 \mathrm{~km}$ have been drawn almost in parallel to that of $5 \mathrm{~km}$ passing each depth point on line B. The subduction entrance along line B has been inferred as show in Fig. 4(a) and (b).

\subsection{IIA lithosphere}

Geometry of the upper surface of the IIA lithosphere of the PHS plate has been estimated along line A as follows. First, the depth zero point, which is a kind of subduction entrance in a statical sense, can be taken around the plate material boundary proposed by Nakamura et al. (1984) in the northern periphery of Hakone volcano. The bases include the facts that the middle Miocene submarine volcanics, which are the oldest exposed basement rocks of the Izu Peninsula, lie as high as $550 \mathrm{~m}$ above sea level even in the northern part of the Hakone caldera (Nakamura et al., 1984), and that on the immediate north of Hakone volcano there exists the paleo-trough II where the buoyant subduction of IIA had been continuing since late Pliocene till early Pleistocene. In this paleo-trough-II area the upper surface of the IIA crust is inferred to be considerably deep now (e.g., Nakamura et al., 1984).

To the north of this area, there is a remarkable site of continual seismicity in eastern Yamanashi Prefecture in the depth range of $15 \sim 30 \mathrm{~km}$ under the Tanzawa Mountains (see Figs. 11 and 12). Earthquakes are occurring due to the maximum compressional stress roughly in the NW-SE direction. By interpreting this activity as the manifestation of the underground collision of the tip of the buoyant IIA crust against the Honshu block, the depth of $15 \mathrm{~km}$ can be drawn as shown in Fig. 4(a). Then, rough estimation of the depths of $5 \mathrm{~km}$ and $10 \mathrm{~km}$ has been made by interpolation.

\subsection{West-Sagami-Bay Fracture (WSBF)}

The subduction entrances of IOA and IIA are located about $50 \mathrm{~km}$ apart from each other. It is impossible to connect them smoothly on the surface. Moreover, there is a large difference in depth between the upper surfaces of IOA and IIA lithospheres. The two surfaces can never be connected smoothly. Therefore, it is very simply concluded that there exists a north-south striking tear fault within the PHS plate. Since the upper edge of this fault coincides with the upper surface of the IOA lithosphere, it should become deeper toward the north. Although the tear within the PHS plate may not be a single sharp fault plane but a fracture zone with a few or several kilometer thickness, as the first-order approximation, the location of its upper edge has been inferred as the thick broken line in Fig. 4(a) (note again that this is the surface projection of the buried upper edge). Ishibashi (1988b) called this fault 'West-Sagame-Bay Fracture' (WSBF). WSBF is regarded as the present manifestation of a tear fault which had separated descending IOA crust from the buoyant IIA crust during the entire course of the PHS plate convergence in SFM. The prolongation of WSBF to the north smoothly continues to the western edge of the Kanto slab shown by Noguchi (1985).

\section{Sub-faulting during the 1923 Kanto Earthquake}

Another strong basis for WSBF is a sub-faulting in the northwestern part of Sagami Bay at the time of the 1923 great Kanto earthquake. The occurrence of this sub-faulting, a reverse faulting striking roughly north-south and westerly dipping, simultaneously with the interplate mega-thrusting along the Sagami trough is beyond doubt, as Ishibashi (1985) discussed in detail. The evidence is the remarkable coseismic crustal uplift of the northwestern coast of Sagami Bay, especially 2 or 3 meter uplift of the tip of Manazuru Cape and about 1.8 meter uplift of the whole Hatsu-shima Island (for locations, see Fig. 4(a)). Obviously, these coseismic crustal deformation can never be explained by various fault mod- 


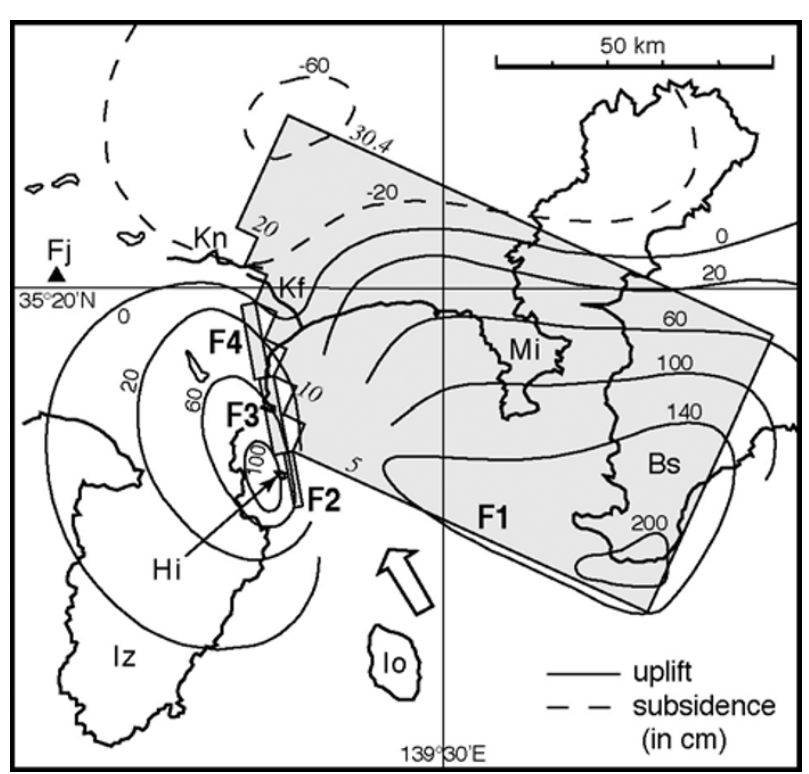

Fig. 5. Vertical surface displacement field (in $\mathrm{cm}$ ) calculated for a trial static fault model of the 1923 Kanto earthquake in the framework of the WSBF hypothesis (Ishibashi, 1988a). Surface projections of four fault planes $(\mathrm{F} 1 \sim \mathrm{F} 4)$ are shown. $\mathrm{F} 1$ models a plate-boundary mega-thrust (dip direction, $\mathrm{N} 24^{\circ} \mathrm{E}$; dip angle, $25^{\circ}$; maximum length, $96 \mathrm{~km}$; width, $60 \mathrm{~km}$; depths of the upper and lower edges, 5 and $30.4 \mathrm{~km}$, respectively, as shown by italic numerals; dislocation amount, 6 meters). F2, F3 and F4 model WSBF (dip direction, N100 ${ }^{\circ}$; dip angle, $80^{\circ}$; length/width/upper-edge-depth, $10 \mathrm{~km} / 10 \mathrm{~km} / 2 \mathrm{~km}, 14 \mathrm{~km} / 15 \mathrm{~km} / 10 \mathrm{~km}$ and $14 \mathrm{~km} / 15 \mathrm{~km} / 15 \mathrm{~km}$, respectively; dislocation amount, 6 meters). White arrow represents the slip vector of the PHS plate $\left(\mathrm{N} 30^{\circ} \mathrm{W}\right)$. Bs, Boso Peninsula; Fj, Mt. Fuji; Hi, Hatsu-shima Island; Io, Izu-Oshima Island; Iz, Izu Peninsula; Kf, Kozu-Matsuda fault; Kn, Kan'nawa fault; Mi, Miura Peninsula.

els so far proposed by Ando (1971), Matsu'ura et al. (1980), Wald and Somerville (1995) and many others. Such a subfaulting is also in harmony with the violent ground shaking on the northwestern coast of Sagami Bay including Hatsushima Island (Ishibashi, 1985).

In Ishibashi's (1985) static fault model of the 1923 Kanto earthquake, a low-angle left-lateral reverse fault (dip direction, $\mathrm{N} 75^{\circ} \mathrm{W}$; dip angle, $30^{\circ}$; length, $30 \mathrm{~km}$; depth of the upper edge, $1 \mathrm{~km}$; width and dislocation amount, $15 \mathrm{~km}$ and $4 \mathrm{~m}$ for the southern half, $30 \mathrm{~km}$ and $6 \mathrm{~m}$ for the northern half) was hypothesized for the above-mentioned sub-fault, in the framework of the West-Sagami-Bay fault hypothesis. In the revised tectonic model of WSBF, however, a high-angle fault is inferred to have ruptured. Ishibashi (1988a) made a trial fault model in the framework of the WSBF hypothesis as shown in Fig. 5, and got a rather good result of vertical crustal movement, though not yet satisfactory.

Aida (1993), in his work of numerical simulation of historical tsunamis originated in the northwestern part of Sagami Bay, tried eight fault models for the 1923 tsunami, including Ando's (1971) model, model II of Matsu'ura et al. (1980) and Ishibashi's (1985) model. He found that his original model in which a sub-fault representing WSBF was added to the interplate main fault gave the best result (see Fig. 8 and its caption). However, in order to confirm the 1923 subfaulting on WSBF, inversion analyses of coseismic crustal deformation data by assuming its geometry is necessary.

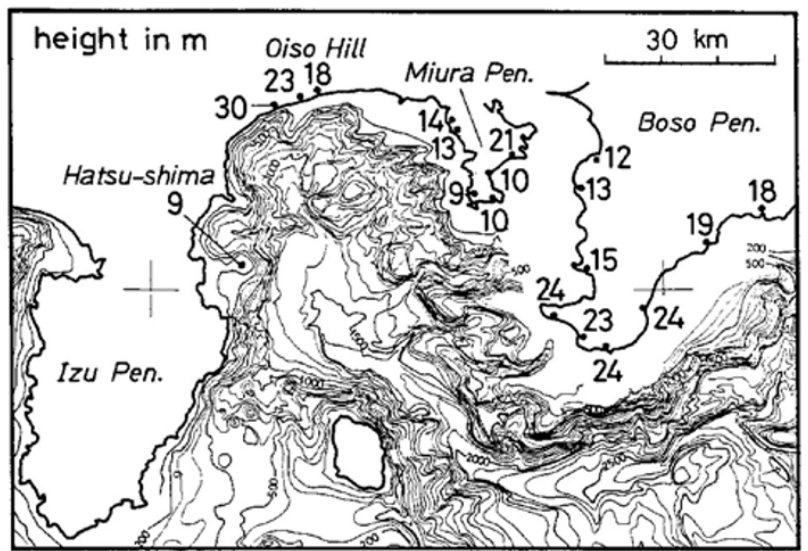

Fig. 6. Altitude (a.m.s.l.) of the highest Holocene marine terrace of about 6,000 years B. P. at Hatsu-shima Island as compared with those at some typical places on the south Kanto coasts (reproduced from figure 12 in Ishibashi et al. (1982)).

The 1923 sub-faulting which caused $1.8 \mathrm{~m}$ uplift of Hatsushima Island is considered to be non-incidental but to have a primary tectonic significance in this area, because the island has been continuously uplifted during at least the last ca. $10^{5}$ years with an average uplift rate of about $1 \mathrm{~m} / 10^{3}$ years (Ishibashi et al., 1982). Although the uplift rate is not among the largest on the south Kanto coasts, the highest Holocene marine terrace, for example, has almost the same altitude as those in the Miura Peninsula (Fig. 6). In addition, as Ishibashi $(1976,1977,1985)$ pointed out, there is a northsouth striking remarkable submarine scarp as high as 1,000 meters in the west part of Sagami Bay (see Figs. 4(a) and 6 ), which also suggests that WSBF is a fundamental tectonic element in this region. The Research Group for Active Faults of Japan (1991) draws a submarine active fault along the foot of this scarp.

\section{Historical Earthquakes around Odawara}

The fact that Odawara suffered severe damage by earthquakes five times every ca. 70 years does not necessarily mean the space-time regularity of underground seismic faulting in the Odawara area. Since the soil condition in the central part of Odawara City is not good, the city may suffer heavy damage by large earthquakes originated various places around Odawara. Moreover, Usami's $(2002,2003)$ earthquake catalogue lists up 10 earthquakes which caused any damage to Odawara since the 17 th century.

Ishibashi (1977, 1985), however, inferred that the large earthquake occurrence just beneath Odawara, itself, had a remarkable temporal regularity of ca. 70 year repeat time, through examination of historical earthquakes. Ishibashi (1988b, 1993) further investigated historical Odawara earthquakes, and there has been more progress in historical seismology in general after that (Ishibashi, 2004). Table 1 summarizes the latest results on historical earthquakes that affected Odawara.

The keys to identify a $M$ 7-class (shallow) earthquake beneath the Odawara area are the sharp contrast of seismic intensities at Odawara (6 or 7 on the JMA scale) and in Edo (4 to 5 on the JMA scale), about $75 \mathrm{~km}$ away from 
Table 1. Earthquakes that caused damage to Odawara since the 17 th century.

\begin{tabular}{|c|c|c|c|c|}
\hline $\begin{array}{l}\text { Date and } \\
\text { time }\end{array}$ & $M(1)$ & $\begin{array}{c}\text { S. I. at } \\
\text { Odawara (6) } \\
\end{array}$ & $\begin{array}{l}\text { S. I. at } \\
\text { Edo (6) } \\
\end{array}$ & Remarks \\
\hline $\begin{array}{l}1633 \mathrm{Mar} .1 \\
\text { ca. } 5 \mathrm{~h}\end{array}$ & $\begin{array}{l}7.0 \pm 1 / 4(2) \\
7.1 \sim 7.2(3) \\
\text { about } 7.0(4)\end{array}$ & 7 & $4 \sim 5$ & $\begin{array}{l}\text { Kan'ei Odawara earthquake. In Odawara, castle destroyed and many houses collapsed, ground fissure } \\
\text { and liquefaction, } 150 \text { or } 230 \text { dead. In Mt. Hakone, landslide, rock-fall and deaths. In Edo, strong shaking } \\
\text { but no damage record. Tsunami at Atami, Ajiro and Usami. Felt aftershocks for about } 20 \text { days in Edo. }\end{array}$ \\
\hline $\begin{array}{l}1645 \text { Nov. } 3 \\
7 \sim 9 \mathrm{~h}\end{array}$ & $\cdots$ & $4 \sim 5$ & about 3 & Slight damage to Odawara castle. Felt in Edo. No record of aftershocks. \\
\hline $\begin{array}{l}1647 \text { Jun. } 16 \\
5 \sim 7 \mathrm{~h}\end{array}$ & $6.5 \pm 1 / 4(2)$ & 5 & 5 & $\begin{array}{l}\text { In Odawara, castle's stone walls, fences and gates broken and a small number of houses collapsed. In Edo, } \\
\text { castle's stone walls and feudal lords' residences damaged, felt aftershocks for about a month, many shocks } \\
\text { further followed and another strong quake in September. }\end{array}$ \\
\hline $\begin{array}{l}1648 \text { Jun. } 13 \\
11 \sim 13 \mathrm{~h}\end{array}$ & $\begin{array}{l}\text { about } 7.0(2) \\
\text { about } 6(4)\end{array}$ & 5 & 4 & $\begin{array}{l}\text { In Odawara, castle's stone walls and fences partly broken, some roofing tiles fell down. In Mt. Hakone, } \\
\text { death by rock-fall. In Edo, long-period strong shaking but no damage record. No record of aftershocks. } \\
\text { Felt also in Kyoto and Shikoku? Possibly a large far-off-shore or deep earthquake. }\end{array}$ \\
\hline $\begin{array}{l}1703 \text { Dec. } 31 \\
2 \sim 3 \mathrm{~h}\end{array}$ & $7.9 \sim 8.2(2)$ & $7(2)$ & $5 \sim 6(2)$ & $\begin{array}{l}\text { Genroku Kanto earthquake. Essentially, a great interplate earthquake along the northern part of the } \\
\text { Sagami trough. Violent earthquake disaster and large tsunami in the whole southern Kanto district. } \\
\text { Though the source region was wider than in } 1923 \text { to the southeast, the feature in the Sagami Bay area was } \\
\text { the same as in } 1923 \text {. Odawara's ground motion and damage were the heaviest; castle and town totally } \\
\text { collapsed and burnt out, about } 850 \text { deaths. Oiso coast was uplifted as well as the Miura Boso coasts. }\end{array}$ \\
\hline $\begin{array}{l}1782 \text { Aug. } 23 \\
1 \sim 3 \mathrm{~h}, 19 \sim 21 \mathrm{~h}\end{array}$ & $\begin{array}{l}\text { about } 7.0(2) \\
7.2 \sim 7.3(3) \\
\text { about } 7(4) \\
7.2(5)\end{array}$ & 6 & 5 & $\begin{array}{l}\text { Ten'mei Odawara earthquake. Second event was a little larger. In Odawara, damage was lighter than in } \\
1633,1703 \text { and 1923; castle's main tower tilted, turrets and stone walls broken, } 800 \text { houses broken. In } \\
\text { Edo, slight damage. No tsunami. Aftershocks lasted at least several days. }\end{array}$ \\
\hline $\begin{array}{l}1843 \text { Mar. } 9 \\
10 \sim 11 \mathrm{~h}\end{array}$ & $6.5 \pm 1 / 4(2)$ & 5 & 4 & $\begin{array}{l}\text { In Odawara, slight damage to castle and town. More damage around the northwestern part of Kanagawa } \\
\text { Prefecture. In Edo, sloshing out of water tanks. }\end{array}$ \\
\hline $\begin{array}{l}\text { 1853 Mar. } 11 \\
9 \sim 11 \mathrm{~h}\end{array}$ & $\begin{array}{l}6.7 \pm 0.1(2) \\
\text { a little under } 7(3)\end{array}$ & $6 \sim 7$ & $4 \sim 5$ & $\begin{array}{l}\text { Ka'ei Odawara earthquake. } 24 \sim 100 \text { deaths. Odawara's damage was lighter than } 1633,1703 \text { and } 1923 \text { but } \\
\text { heavier than } 1782 \text {; many castle's structures and town houses destroyed. In Edo, slight damage. Small } \\
\text { tsunami at Manazuru. Many aftershocks. }\end{array}$ \\
\hline $\begin{array}{l}1870 \text { May } 12 \\
\text { ca. } 4 \text { h }\end{array}$ & $6.0 \sim 6.5(2)$ & 5 & $3 \sim 4$ & $\begin{array}{l}\text { Walls, fences and roofing tiles broken in Odawara castle. Other damage records unknown. Note that } \\
\text { Odawara castle was devastated after the Meiji Restoration of } 1868 \text {. Seems earthquakes had been } \\
\text { continuing since around May } 2 \text { nd. }\end{array}$ \\
\hline $\begin{array}{l}1923 \text { Sep. } 1 \\
\text { 11:58 }\end{array}$ & $7.9(2)$ & 7 & $5 \sim 6$ & $\begin{array}{l}\text { Taisho Kanto earthquake. Essentially, a great interplate earthquake along the northern part of the Sagami } \\
\text { trough. Violent earthquake disaster and large tsunami in the whole southern Kanto district. Odawara's } \\
\text { ground motion and damage were the heaviest; large-scale collapse of the castle's stone walls, most houses } \\
\text { collapsed and burnt out. }\end{array}$ \\
\hline
\end{tabular}

(1) equivalent to $M_{J}$, magnitude assigned by JMA (e.g., Ishibashi, 2004); (2) after Usami (2003); (3) after Ishibashi (1993); (4) after Matsu'ura et al. (2002); (5) after Tsuji (1986); (6) Seismic intensity on the JMA scale estimated by Ishibashi (1993) (slightly modified) except for the 1703, 1870 and 1923 earthquakes (Estimation for the 1870 and 1923 events is from the present study). + and - mean the upper and the lower levels, respectively.

Odawara, and many successive felt earthquakes (presumable aftershocks). Although Usami's (2002, 2003) catalogue still lists the 1648 earthquake as an event near Odawara with the same epicentral coordinates as those of 1633 and with magnitude 7 , this is clearly misinterpretation judging from the above-mentioned criteria (Ishibashi, 1978, 1985, 1993; see Table 1). Events in 1645, 1647, 1843 and 1870 are also eliminated from the category of $M 7$ earthquakes beneath Odawara in the same way.

Figure 7 illustrates distributions of seismic intensities and tsunamis for the three $M 7$ Odawara earthquakes in 1633, 1782 and 1853. Although seismic intensity at each place more or less includes site effects (e.g., three ' 6 ' around 'Ni' in southeast Yamanashi Prefecture in 1782 may have been amplified by surface geology), I estimated source regions of these earthquakes as shown in Fig. 7 based on the illustrated data and assuming their occurrence on WSBF. Of course, macroseismic data alone cannot prove this assumption, but there is no other tectonic element whose rupture explains these distributions of ground motions and tsunamis. If we make this assumption, we can estimate three source regions reasonably. Though Ishibashi (1985) inferred their source regions on the hypothetical low-angle West-Sagami-Bay fault, we can re-estimate them on the high-angle WSBF because the east-west widths of the source regions are not very important.

Concerning the 1633 Kan'ei Odawara earthquake,
Matsu'ura et al. (2002) proposed a different interpretation that this earthquake had been a low-angle reverse faulting along the Kozu-Matsuda fault and its southeastern extension under the sea bottom. If so, strong ground motion is expected on the hanging-wall side (east side) of the KozuMatsuda fault, but there is no evidence for that. Rather, a diary written by the Director of Dutch Trading House, who was traveling to Edo passing through Odawara and Oiso (for location, see Fig. 7(c)) about eight months after the disaster, suggests no severe damage to the east of the Kozu-Matsuda fault, whereas it describes serious damage and reconstruction of Odawara. On the basis of the strongest ground motion at Odawara and tsunamis at Atami, Ajiro and Usami (e.g., Ishibashi, 1985) the 1633 source region is estimated as in Fig. 7(a).

As for the 1782 Ten'mei Odawara earthquake, after Ishibashi (1985) concluded that there had been no tsunami and inferred its source region to be inland north of Odawara, Tsuji (1986) claimed that it had generated tsunami. Following this opinion Usami's (2002) earthquake catalogue in English says "tsunami hits Odawara and Atami." Tsuji's conclusion was, however, drawn by very intricate interpretation of historical documents which did not give any explicit description of tsunami. Ishibashi (1997) demonstrated both seismological and historiographical contradiction and problems in Tsuji's (1986) interpretation, and concluded again that the 1782 earthquake had not generated tsunami and its 

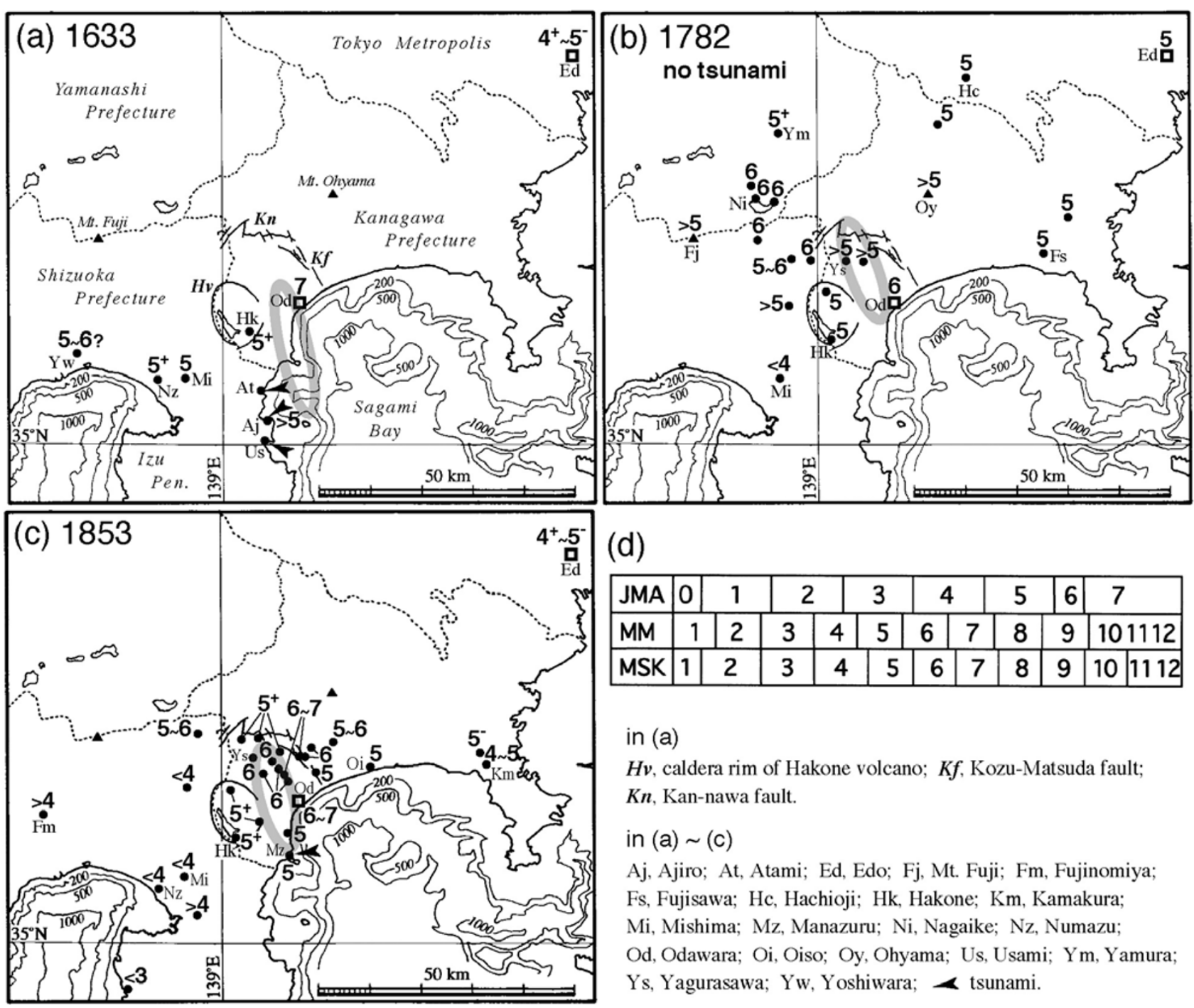

(d)

\begin{tabular}{|l|c|c|c|c|c|c|c|c|c|c|c|}
\hline JMA & 0 & 1 & \multicolumn{2}{|c|}{2} & \multicolumn{2}{|c|}{3} & 4 & 5 & 6 & 7 \\
\hline MM & 1 & 2 & 3 & 4 & 5 & 6 & 7 & 8 & 9 & 101112 \\
\hline MSK & 1 & 2 & 3 & 4 & 5 & 6 & 7 & 8 & 9 & 10 & 1112 \\
\hline
\end{tabular}

in (a)

$H \boldsymbol{v}$, caldera rim of Hakone volcano; $K f$, Kozu-Matsuda fault; $K n$, Kan-nawa fault.

in (a) $\sim$ (c)

Aj, Ajiro; At, Atami; Ed, Edo; Fj, Mt. Fuji; Fm, Fujinomiya; Fs, Fujisawa; Hc, Hachioji; Hk, Hakone; Km, Kamakura; Mi, Mishima; Mz, Manazuru; Ni, Nagaike; Nz, Numazu; Od, Odawara; Oi, Oiso; Oy, Ohyama; Us, Usami; Ym, Yamura; Ys, Yagurasawa; Yw, Yoshiwara; 4 tsunami.

Fig. 7. Distributions of seismic intensities and tsunamis (arrows) for the three historical Odawara earthquakes (modified from figure 1 in Ishibashi (1993) which revised Ishibashi's (1985) results). Seismic intensities are on the JMA (Japan Meteorological Agency) scale, and the comparison among JMA, MM and MSK scales (Ishibashi, 2004) is shown in (d). (a) shows all data for the 1633 Kan'ei Odawara earthquake, and (b) (c), near-field data for the 1782 Ten'mei Odawara and the $1853 \mathrm{Ka}$ 'ei Odawara earthquakes, respectively. '+', '-', '>' and '<' represent upper level, lower level, 'larger than' and 'smaller than', respectively. Inferred source regions (stippled ellipses) are also shown. For full locality names, see Ishibashi (1993).

source region had lain on the inland side of Odawara.

The 1853 Ka'ei Odawara earthquake had been considered not to have generated tsunami (e.g., Ishibashi, 1985). However, Ishibashi (1988b) suggested a possibility of tsunami based on a historical description, and Aida (1993), by careful examinations of historical records, verified that slight tsunami hit a small bay at Manazuru. Based on this tsunami and seismic intensity distribution the source region is estimated as shown in Fig. 7(c). The following noteworthy historical description (Ishibashi, 1993) suggests an aftershock distribution in harmony with this estimation; among many aftershocks, one was felt strong near Manazuru, another shook strongly around the northern edge of the estimated source region causing landslide, and another was so strong as Japanese sliding doors were off their grooves near the eastern mouth of the caldera rim of Hakone volcano.

Aida (1993) carried out numerical simulations of historical tsunamis originated in Sagami Bay by assuming six, six, two and eight fault models for the 1633, 1703, 1853 and 1923 tsunamis, respectively. He found that the best fault models for the 1633, 1853 and 1923 tsunamis were those incorporating WSBF as shown in Fig. 8.

As discussed by Ishibashi $(1985,1993)$, at the time of the 1703 great Genroku Kanto earthquake, strong ground motions, tsunamis, and aftershock occurrence on the north to west coast of Sagami Bay and its inland adjacencies were very similar to those in 1923, and a sub-faulting like in 1923 on WSBF is inferred to have taken place, though there is no direct evidence yet. According to Aida's (1993) tsunami simulation, however, a fault model which does not include a sub-fault on WSBF is the best for this event to explain the initial tsunami motion at Usami (for location, see Figs. 7 and 8) of up. But, there remains a question on this model because the initial motion of tsunami at Usami in 1923, when a subfaulting evidently took place, was also up (e.g., Ishibashi, 1985). Thus, a sub-faulting on WSBF in 1703 is possible but awaiting further investigation.

Figure 9 is the plot of occurrence times of five presumable 


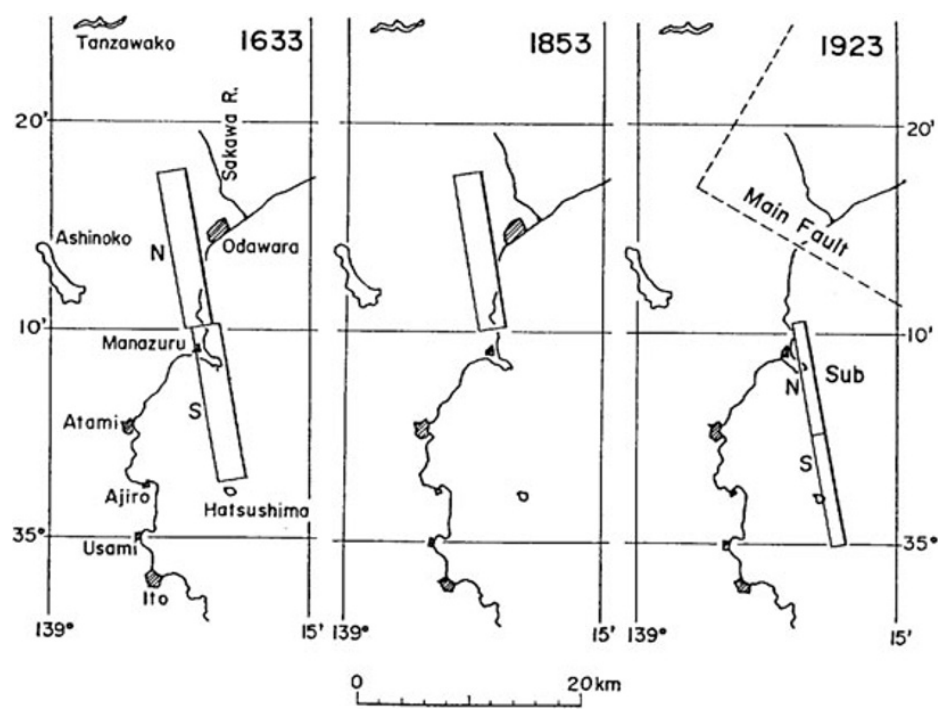

Fig. 8. Best fault models for three historical tsunamis originated in the northwestern part of Sagami Bay obtained by Aida (1993) (reproduced from figure 7 in the paper). Solid rectangles are horizontal projections of fault planes modeling WSBF (dip direction, N100 ${ }^{\circ} \mathrm{W}$; dip angle, $80^{\circ}$; left-lateral reverse fault). Length, width, depth of the upper edge and dislocation amount of each fault plane are as follows. $1633 \mathrm{~N} ; 14 \mathrm{~km}, 14 \mathrm{~km}, 5 \mathrm{~km}$ and 5 meters. $1633 \mathrm{~S} ; 14 \mathrm{~km}, 14 \mathrm{~km}, 2 \mathrm{~km}$ and 5 meters. 1853; the same as $1633 \mathrm{~N}$. 1923N; $10 \mathrm{~km}, 7 \mathrm{~km}, 2 \mathrm{~km}$ and 5 meters. $1923 \mathrm{~S} ; 10 \mathrm{~km}, 7 \mathrm{~km}, 1 \mathrm{~km}$ and 5 meters.

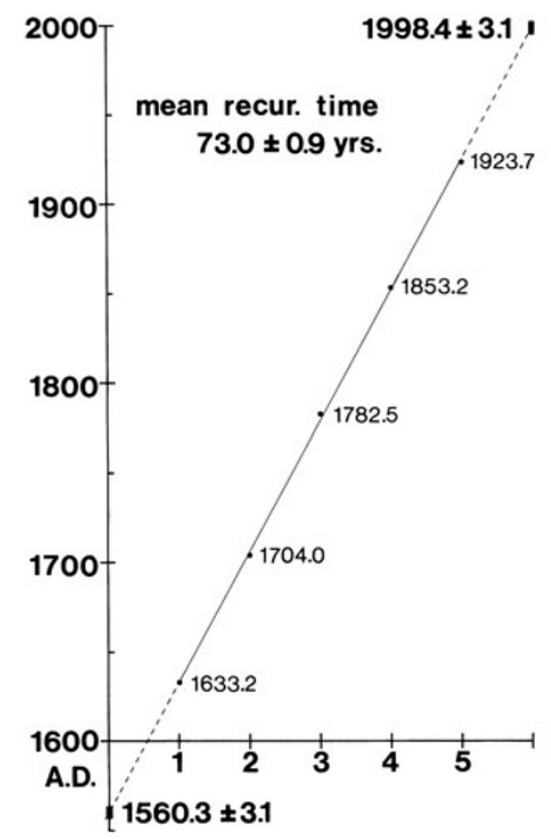

Fig. 9. Event number versus occurrence time (in year) plot for five seismic faultings presumed on WSBF (reproduced from figure 4 in Ishibashi (1988b)). The simple linear regression line, mean recurrence time with standard deviation and estimated times of the 0th and 6th events with standard deviations are also shown.

WSBF ruptures versus event numbers (Ishibashi, 1988b). A simple linear regression gives the mean recurrence time of 73.0 years. The estimated occurrence year of the 0th earthquake is $1560.3 \pm 3.1$. Although earthquake records around Odawara is very poor before the 16th century because the area was far from the political and cultural center of Japan except for the Kamakura period (1192-1333), there is, by chance, a fragmentary historical record on a seismic event at Odawara around this time point. Ryuenji Nendaiki, a chron- icle of Ryuenji Temple located to the north of Odawara at a distance of about $100 \mathrm{~km}$ written in the early $17 \mathrm{th}$ century, says that there were earthquakes at Odawara from May 26 till June 1, 1556 (converted to the Julian calendar from the original Japanese lunar calendar) (Tsuji, 1985; Ishibashi, 1993). There is no other information at all so far, but a remarkable earthquake and its aftershocks may have occurred in the Odawara area. It should be emphasized that we cannot deny the earthquake recurrence in the Odawara area in older times if we understand the incompleteness of historical earthquake records in the Japanese Islands (e.g., Ishibashi, 2004).

\section{Nature of the West-Sagami-Bay Fracture}

As logical consequences of long-term subduction/collision process of IOA and IIA as examined in Section 3, and of present-day remarkable discontinuity of underground geometry of the IOA and IIA crusts together with their subduction entrances as clarified in Section 4, a tear fault within the PHS plate, West-Sagami-Bay Fracture (WSBF), should exist beneath the northwestern part of Sagami Bay and its northern inland adjacencies. WSBF runs almost north-south, and separates the subducting non-volcanic IOA crust on the east side, which is considered relatively cold and less buoyant, from the colliding volcanic IIA crust on the west side, which is considered relatively warm and buoyant. Its upper edge becomes deeper toward the north. Since there is a westward component in the relative motion of the PHS plate, WSBF is considered to have a thrust component (westerly dipping, high-angle, left-lateral reverse fault, as a whole).

The rupture zones of the 1633, 1782, 1853 Odawara earthquakes and the 1923 sub-faulting estimated before are assigned on WSBF as shown in Fig. 10(a), (b). In these figures it is assumed that in 1703 almost the same-scale sub-faulting as in 1923 took place. 
Figure 10(c) shows schematically the distribution of the slip vectors on WSBF. The velocity vector of the buoyant IIA crust is considered horizontal all along WSBF from south to north, but the rate is inferred to decrease toward the north because of the collision. On the other hand, the velocity of the down-going IOA crust along WSBF is considered constant, but the vector probably declines gradually toward the north. As the result, it is presumed that the slip vector of WSBF is small and horizontal in the southern part and becomes larger with increasing vertical (thrust) component in the northern part, that is, the slip angle and the slip rate on WSBF increase toward the north.

The 1980 Izu-Hanto-Toho-Oki (East-off-Izu-Peninsula) earthquake ( $M$ 6.7), a left-lateral strike-slip faulting on a shallow vertical plane with a strike of $\mathrm{N} 10^{\circ} \mathrm{W}$ (Takeo, 1988; see Fig. 4(a)), has been sometimes referred to as a contradiction to the hypothesized WSBF. This event, however, took place just on the southern extension of WSBF, representing the motion at P in Fig. 10(c), and, hence, was in harmony with the WSBF hypothesis.

The maximum slip rate on WSBF is roughly estimated at about $3 \mathrm{~cm} / \mathrm{yr}$, because the velocity of the IIA crust is almost zero and the velocity of the IOA crust is almost equal to that of the PHS plate, $3 \mathrm{~cm} / \mathrm{yr}$. The mean repeat time of 73 years for a $M 7$ earthquake is reasonable in view of this estimation. Inferred rupture areas of five events are in harmony with the tectonic consideration on the geometry and strain rate distribution of WSBF. An asperity-like portion that ruptures in every event may exist just beneath Odawara (Fig. 10(b)), which may control the regular recurrence.

WSBF is not evident in recent seismicity. Figures 11 and 12 show the high-quality hypocenter distribution in and around the Izu collision zone during the period from October 1997 through December 2003. There are several noticeable seismic activities around WSBF such as the east-offIzu earthquake swarm, very shallow volcanic earthquakes in the Hakone caldera, and the eastern-Yamanashi earthquakes around $35.5^{\circ} \mathrm{N} / 139^{\circ} \mathrm{E}$.

Yoshida $(1990,1993)$ paid special attention to the notable earthquake belt running from south to north along the western border of Kanagawa Prefecture (along $139.1^{\circ} \mathrm{E}$, from around $35.2^{\circ} \mathrm{N}$ to around $35.4^{\circ} \mathrm{N}$ in Fig. 11(a)), and called it 'Doshi-Odawara seismic zone.' He interpreted that the sharp western boundary of this seismic zone represented an intraplate fracture of the PHS plate, which was the boundary between the subducting Kanto slab and the colliding Izu block, and considered that the boundary continued to the Tan'na fault (main part of the Kita-Izu active fault system; $\mathrm{Ki}$ in Figs. 4(a) and 13). However, this interpretation is hard to accept because it disregards such remarkable tectonic features as the 1923 coseismic uplift of the west coast of Sagami Bay and late-Quaternary continuous uplift of Hatsu-shima Island. At the same time, tectonic meaning of Odawara earthquakes is unclear in this interpretation.

As for the 'Doshi-Odawara seismic zone,' Ishibashi (1993) considered that it was a seismic activity in the hanging-wall side of WSBF caused basically by a left-lateral compressional stress accumulation, and that the sharp western boundary was probably an eastern border of the warm volcanic block of aseismic nature. The P-axes in this seis-
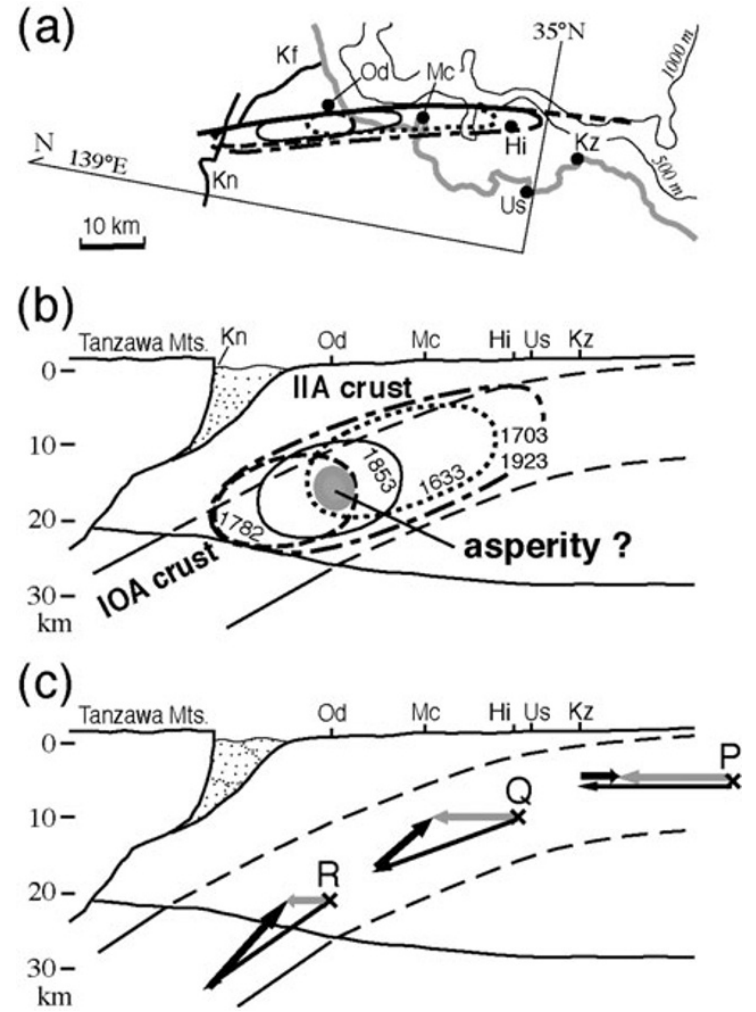

Fig. 10. (a) and (b) show inferred rupture zones of five historical seismic faultings on WSBF (modified from figure 3 in Ishibashi (1988b)). (a) is a map view and (b) is the vertical cross section. Thick solid and broken line in (a) represents surface projection of the upper edge of WSBF. Thin lines of $500 \mathrm{~m}$ and $1000 \mathrm{~m}$ in (a) are isobaths in Sagami Bay. The styles of lines delineating source regions of five events in (a) and (b) correspond each other. (c) shows schematically velocity vector of the IOA crust (thin black arrows), that of the IIA crust (grey arrows) and slip vector on WSBF (thick black arrows) on three representative points, P, Q and R. Hi, Hatsu-shima Island; Kf, Kozu-Matsuda fault; Kn, Kan'nawa fault; Kz, Kawanazaki Point; Mc, Manazuru Cape; Od, Odawara; Us, Usami.

mic zone are mostly in the direction of NNW-SSE to NW-SE (e.g., Ishida, 1993). In 1990, a $M 5.1$ earthquake, a dip-slip event with a NW-SE P-axis and a high stress drop of 880 bar, occurred in this zone at a depth of $17 \mathrm{~km}$ (Ishida and Kikuchi, 1992). Ishida and Kikuchi (1992) proposed that this event was a possible foreshock of a future large Odawara earthquake, and that the future event would be the same-type faulting as the 1990 one within the subducted PHS plate. Hagiwara (1993) referred to this earthquake and suggested different mechanism of the $M 7$ Odawara earthquake from the WSBF hypothesis. My interpretation, on the contrary, is that this event took place in the hanging-wall side of WSBF, matching the WSBF hypothesis and reflecting a high-stress state along WSBF.

Figure 13 is a schematic bird's-eye view summarizing the WSBF hypothesis. Odawara is located very near to IIA proper, but is considered to exist on an accretionary wedge overriding the IOA lithosphere. Basically, there should be no differential motion between the IIA crust on the west and the accretionary wedge on the east in the shallower part above the upper edge of WSBF.

In Fig. 13 two pairs of short arrows between Izu-Oshima Island and the east coast of the Izu Peninsula show that 
(a) depth, 0 33 km

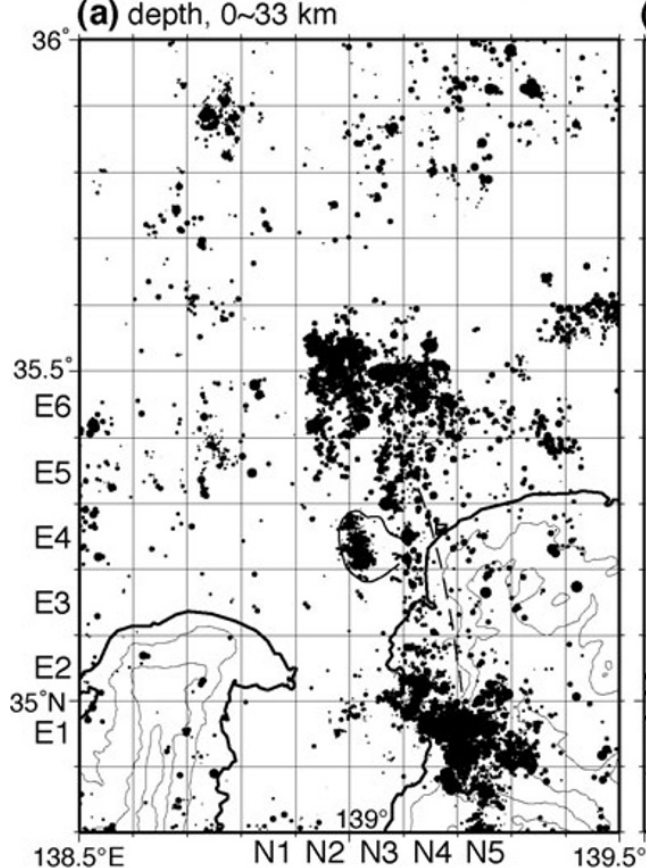

Oct.1, 1997 - Dec.31, 2003

(b) depth, 33 $80 \mathrm{~km}$

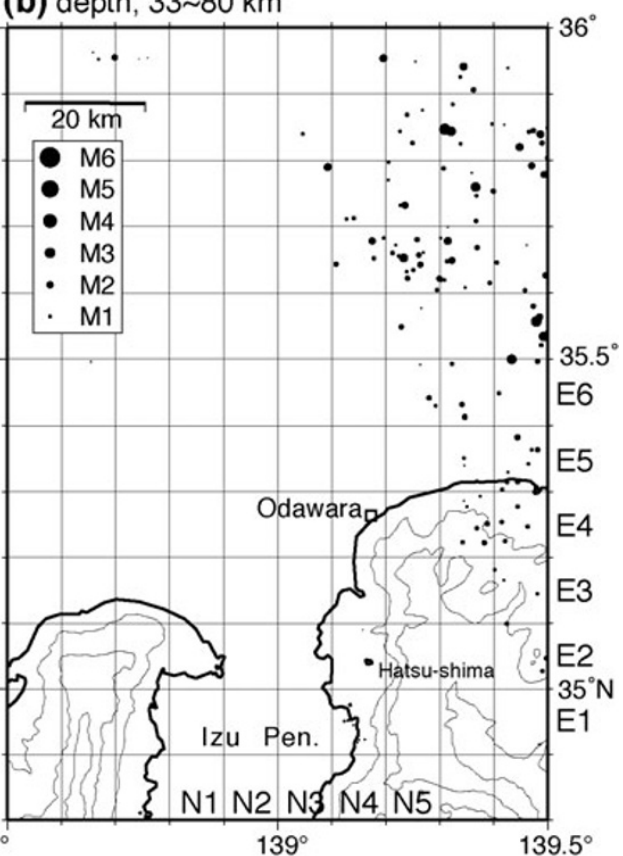

Fig. 11. Epicentral distributions of earthquakes in and around the Izu collision zone during the period from October 1, 1997 to December 31,2003 for two depth ranges. Data are from the integrated hypocenter database prepared by the Japan Meteorological Agency. In (a), surface projection of the upper edge of WSBF (broken line) and the caldera rim of Hakone volcano (solid curve) are shown. E1 E6 and N1 N5 indicate belts of vertical cross sections shown in Fig. 12. Isobaths are every 500 meters.
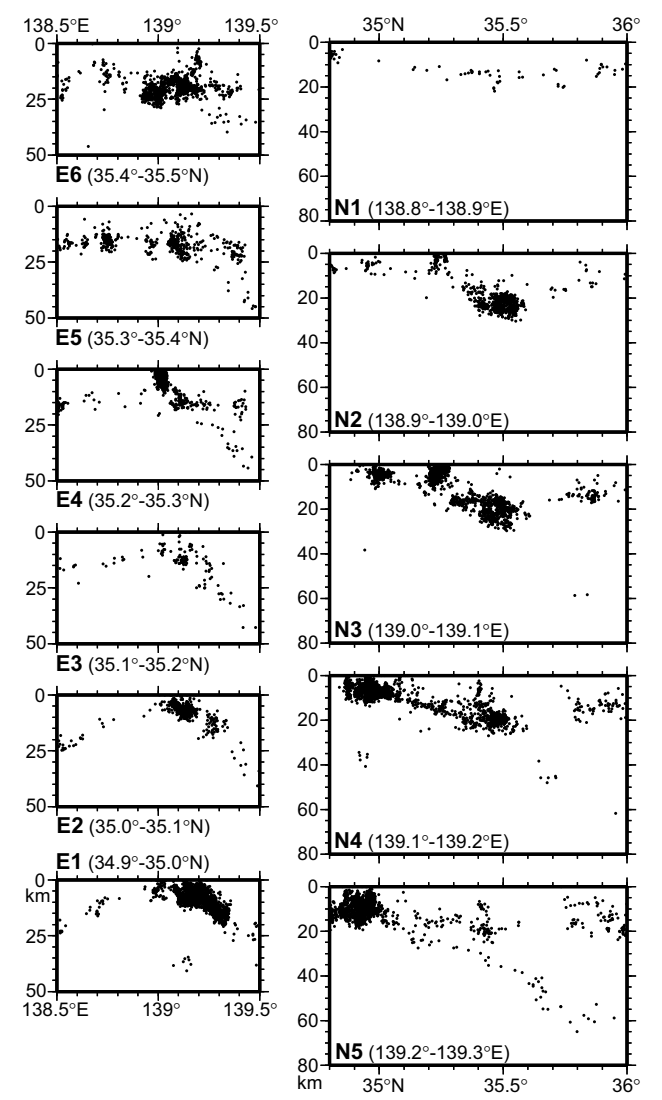

Fig. 12. Vertical cross sections of hypocentral distribution of the earthquakes shown in Fig. 11. $0.1^{\circ}$-width EW cross sections for the depth range of $0-50 \mathrm{~km}$ from $34.9^{\circ} \mathrm{N}$ to $35.5^{\circ} \mathrm{N}\left(\mathrm{E} 1 \sim \mathrm{E} 6\right.$; left) and $0.1^{\circ}$-width NS cross sections for the depth range of $0-80 \mathrm{~km}$ from $138.8^{\circ} \mathrm{E}$ to $139.3^{\circ} \mathrm{E}(\mathrm{N} 1 \sim \mathrm{N} 5$; right $)$ are shown. around the subduction entrance, presumably, a tensional stress field perpendicular to the strike of the entrance $\left(\sigma_{3}\right.$ in the NNE-SSW direction) is predominant in the IOA crust due to the bending associated with subduction. This feature can explain why the remarkable east-off-Izu earthquake swarm, which is considered to be caused by dike intrusion (e.g., Okada et al., 2000), has been localized in this particular area, mostly south of $35^{\circ} \mathrm{N}$ (see Fig. 11(a)), for more than 20 years. This stress field is considered to permeate into IIA to some extent causing swarm activity also in the IIA crust. Anyway, it is noteworthy that the stress fields around the southern end of WSBF and along its northern part exhibit marked contrast with each other.

Sometimes a question is addressed whether there is 'EastSuruga-Bay Fracture' or not. The essential causes of WSBF are the existence of the volcanic front and differences in nature and behavior between IOA and IIA. In contrast to these situations in Sagami Bay, in the Suruga Bay region, almost uniform lithosphere of the western margin of IIA has been subducted beneath the Tokai district, and there are not such conditions. In addition, the direction of the PHS plate motion is not parallel to the major trend of tectonic structure in the Sagami Bay-Izu Peninsula-Suruga Bay region, but asymmetric. Therefore, 'East-Suruga-Bay Fracture' is not postulated.

\section{Discussion}

Kasahara (1985) and Sakata (1987) interpreted the 1633, 1782 and 1853 Odawara earthquakes as interplate events beneath Odawara on a northerly dipping segment of the PHS plate. Kasahara (1985) adopted the western fault plane (F1) of MODEL-III of the 1923 Kanto earthquake proposed 


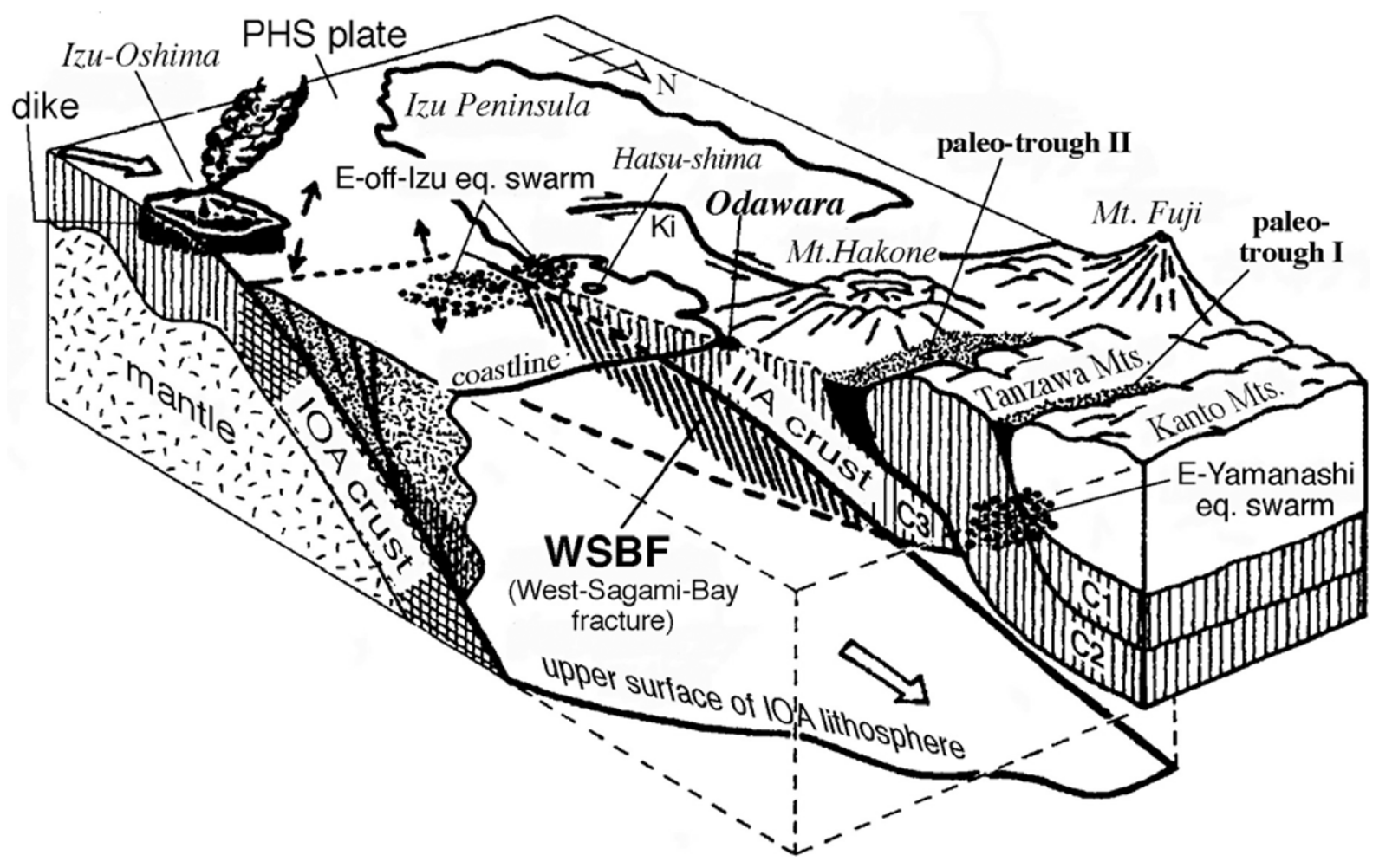

Fig. 13. Schematic bird's-eye view of the three-dimensional PHS plate geometry and underground structure around Odawara in SFM representing the WSBF hypothesis (slightly modified from figure 6 in Ishibashi (1988c)). C1, C2 and C3 correspond to those in Fig. 3. Ki denotes the Kita-Izu active fault system.

by Matsu'ura et al. (1980), and Sakata (1987), the idea that the northern surface boundary of the PHS plate ran along an 'Atami-Numazu line' to the south of Hakone volcano (Tada, 1977). However, the view that the PHS plate boundary runs along the F-1 or the 'Atami-Numazu line' conflicts with geological and geomorphological features in this area (e.g., Matsuda, 1993). In addition, Kasahara's (1985) model of the 1633 earthquake was not supported by numerical simulations of tsunami (Aida, 1993).

Ohkouchi (1990) inferred an northerly-dipping active thrust at the southern foot of the Manazuru Knoll (for location, see Fig. 4(a)) in the examination of active geological and topographical structures in Sagami Bay based on many seismic profiling data, and suggested that the PHS plate motion was partly accommodated here. Hagiwara (1993) considered this interpretation as a strong evidence to deny the WSBF hypothesis. However, if the finding of an active thrust is true, it means that the subduction entrance exists to the south of the knoll as Ohkouchi (1990) himself illustrated, very near to the place shown in Fig. 4(a), supporting the geometry of the IOA lithosphere discussed in Section 4. And, after all, the proposed thrust becomes a good evidence to support the WSBF hypothesis as a logical consequence. But, as a matter of fact, the inference of the thrust, itself, is not convincing because of insufficient data and discussion (Ishibashi, 1999). Even if there is a thrust at the southern foot of the Manazuru Knoll, it is considered a small-scale local one because the knoll has very limited lateral dimension.

WSBF has not yet been detected by seismic survey experiments both in Sagami Bay and on land (e.g., Kato et al., 1993; Yoshii, 1993). Hagiwara (1993) referred to this point also as a matter denying the existence of WSBF. But, as was discussed by Yoshii (1993), direct detection of WSBF by reflection/refraction seismic survey is considerably difficult because it is not very large-scale, being situated rather deep under the surface, and probably almost vertical. The essential point of the WSBF hypothesis is a proposal of a new view on the geometry of the subducted IOA lithosphere including the location of its subduction entrance. Therefore, for examining the hypothesis, indirect investigation of WSBF by elucidating the IOA geometry through, for example, a longdistance dense onshore-offshore seismic survey along the line B in Fig. 4(a) is very important. At least crustal structure beneath Sagami Bay obtained by a seismic refraction experiment by using OBS's (Nishizawa et al., 1996) is in harmony with the IOA geometry proposed in Section 4. Anyway, to clarify the PHS plate geometry in and around Sagami Bay is indispensable not only for checking the WSBF hypothesis but also to understand plate tectonics in this region including seismotectonics of interplate Kanto earthquakes.

Koyama (1995), basically supporting the WSBF hypothesis, proposed a modified model of active tectonics around WSBF. He newly hypothesized a 'Manazuru microplate' taking into account the Higashi-Izu (eastern Izu) monogenetic-volcano field in the central part of the Izu Peninsula, the Tan'na fault, the Kozu-Matsuda fault, the Oiso Hills and the Tanzawa Mountains. Although this model seems to be involved mainly with the shallower part, it is worth considering carefully in order to improve the WSBF hypothesis.

An apparently big problem in earthquake recurrence beneath the Odawara area is that the earthquake series does not 


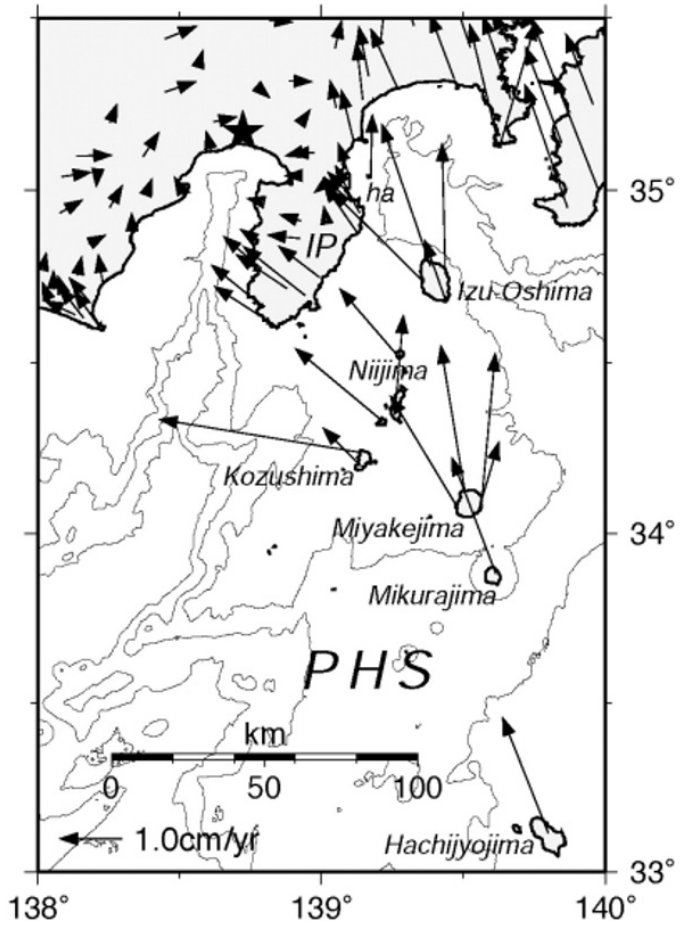

Fig. 14. Horizontal velocity vectors of the GEONET (GPS Earth Observation NETwork operated by Geographical Survey Institute) stations relative to the station 93076 (Fuji; solid star) for the period between November 1998 and June 2000 (reproduced from figure 2 in Ishibashi and Itani (2004)). PHS, IP and ha denote the Philippine Sea plate, the Izu Peninsula and Hatsu-shima Island, respectively. Isobath interval is $1000 \mathrm{~m}$.

have a characteristic earthquake. Obviously, $M$ 7-class local events and $M$ 8-class regional interplate events are mixed, and even among $M$ 7-class Odawara earthquakes, locations of source regions and sizes appear different from event to event, though my interpretation is that this is a reasonable manifestation of the unique nature of WSBF as discussed in the previous section. In addition, a sub-faulting during the 1703 Genroku Kanto earthquake still remains a kind of conjecture. The asperity mentioned in the previous section is yet a very rough idea, though Ohtake (1993) showed that the recent geodetic data supported its existence. Anyway, more detailed consideration of the dynamics of the Odawara earthquakes is necessary.

The anticipated time of the next earthquake by a simple linear regression analysis of five historical events and its standard deviation were $1998.4 \pm 3.1$ (Fig. 9; Ishibashi, 1988b). Ohtake (1993) applied a Weibll distribution to the recurrence intervals of five events, and obtained cumulative probabilities of $18 \%$ as of the beginning of 1993 and $83 \%$ as of the end of the 20th century. Although nearly 81 years have already passed since the last event in 1923, it should be noted that in case of the 1782 earthquake 78.5 years had elapsed since the 1703 great Genroku Kanto earthquake. According to Utsu (1994), it can easily happen, purely statistically, that the time interval between the future and the last events deviates from the recent average of 73 years by 10 years or more, if the Odawara earthquake sequence has a moderately intermittent nature. If we apply the Brownian passage time (BPT) distribution (Ellsworth et al., 1999; Earthquake Research Committee, 2001) to four recurrence intervals from 1633 to
1923, two specific parameters $\mu$ (mean time to failure) and $\alpha$ (aperiodicity of the mean) are 72.6 years and 0.042 , respectively. Since $\alpha$ is surprisingly small, the five-year probability from September 1, 2004 becomes 99.4\%. If we include the 1556 earthquake mentioned in Section 6 in the Odawara earthquake series, then, $\mu, \alpha$ and the five-year probability are $73.5,0.052$ and $95.9 \%$. If we use $\alpha=0.24$ following Earthquake Research Committee (2001), then the five-year probability from September 1, 2004 becomes $25 \sim 26 \%$ for both cases with and without the 1556 event.

Tectonophysically, as Ishibashi (1988c) discussed, the next Odawara earthquake may be delayed because the last rupture of WSBF in 1923 is considered to have been exceptionally large-scale by comparing the $1.8 \mathrm{~m}$ coseismic uplift of Hatsu-shima Island to its average uplift rate of about 1 $\mathrm{m} / 10^{3}$ yrs during the last ca. $10^{4} \sim 10^{5}$ yrs (Ishibashi et al., 1982). In addition, the rupture of the Kita-Izu active fault system (Figs. 4(a) and 13), which is considered an event of every $700 \sim 1,000$ years (e.g., Matsuda, 1993), during the 1930 Kita-Izu earthquake of $M 7.3$ may affect the activity of WSBF, though the mechanism is unknown. In the next Odawara earthquake, northern (inland) part of WSBF seems more likely to break. Anyway, recent GPS observation data show clearly that the Izu-Hakone block is actually colliding against Honshu and along WSBF left-lateral shear strain has been accumulated (Fig. 14; Ishibashi and Itani, 2004).

\section{Conclusion}

A hypothesized WSBF (West-Sagami-Bay Fracture) beneath the northwestern part of Sagami Bay and its northern inland adjacencies is regarded as the present form of a tear fault within the PHS plate which has separated the subducting IOA crust from the buoyant IIA crust during the cource of the PHS plate subduction/collision in SFM. It is considered a north-south striking, high-angle, left-lateral reverse fault in average, but the slip vector on it probably varies from south to north. This fracture is inferred to be causative of the repeating seismic faultings beneath Odawara that recurred five times every ca. 70 years during the last 400 years. In actual situation, WSBF may not be a thin fault plane but a fracture zone with a few or several kilometer thickness. The WSBF hypothesis has not yet been proved nor denied. It still remains the only conceptual model to explain the earthquake recurrence in the Odawara area as well as a comprehensive idea to understand the Neogene to modern plate convergence process in SFM. Since many Japanese seismologists are concerned about a near-future possibility of a large earthquake near Odawara, setting up a source model based on moreimproved seismotectonic interpretation is required.

Acknowledgments. I wish to express my gratitude to Keiiti Aki for inviting me to the Hagiwara Symposium on Monitoring and Modeling of Earthquake and Volcanic Processes for Prediction held on June 30 and July 1, 2003 during the 23rd General Assembly of IUGG in Sapporo, Japan. Thanks are also due to Anshu Jin for her kind help for the Symposium and during the course of preparation of this paper. I am grateful to the Japan Meteorological Agency and the Ministry of Education, Culture, Sports, Science and Technology of the Japanese Government for providing hypocentral data, and to Takayuki Miyoshi and Shigeto Yoritomi for their help in preparing some of the figures. I also thank two anonymous referees and Anshu Jin for their helpful comments. 


\section{References}

Aida, I., Historical tsunamis and their numerical models which occurred in the north-western part of Sagami Bay, Chigaku Zasshi (J. Geography), 102, 427-436, 1993 (in Japanese).

Amano, K., The South Fossa Magna region as a multiple collision zone, Gekkan Chikyu (The Earth Monthly), 8, 581-585, 1986 (in Japanese).

Amano, K., Multiple collision tectonics of the South Fossa Magna in central Japan, Modern Geol., 15, 315-329, 1991.

Ando, M., A fault-origin model of the great Kanto earthquake of 1923 as deduced from geodetic data, Bull. Earthq. Res. Inst., Univ. Tokyo, 49, 19-32, 1971 .

Earthquake Research Committee, Headquarters for Earthquake Research Promotion, Regarding methods for evaluating long-term probability of earthquake occurrence (June 8 2001), 46 pp., in "Reports" at http://www.jishin.go.jp/main/index-e.html, 2001 (in Japanese).

Ellsworth, W. L., M. V. Matthews, R. M. Nadeau, S. P. Nishenko, P. A. Reasenberg, and R. W. Simpson, A physically-based earthquake recurrence model for estimation of long-term earthquake probabilities, USGS Open-File Report, 99-522, 1999.

Furumoto, M., T. Kunitomo, and H. Inoue, Depth contour maps of the discontinuity surfaces of the crust in and around the South Fossa Magna, Modern Geol., 14, 35-46, 1989.

Hagiwara, Y., An overview of studies on the suspected "West Kanagawa Earthquake", Chigaku Zasshi (J. Geography), 102, 337-340, 1993 (in Japanese).

Hamada, N., Note on the focal depth of the 1923 great Kanto earthquake, Kenshin Jiho (Quart. J. Seism.), 50, 1-6, 1987 (in Japanese with English abstract).

Ishibashi, K., "East-off-Izu Tectonic Line" and "West-Sagami-Bay fault" as an origin of the Izu Peninsula uplift: Dual structure of the northernmost boundary of the Philippine Sea plate, Programme and Abstracts, Seism. Soc. Jpn., 1976 No. 2, 29, 1976 (in Japanese).

Ishibashi, K., A possibility of a "West-Sagami-Bay earthquake" and its relation to the Tokai earthquake: Seismotectonics in the Sagami BayIzu Peninsula-Suruga Bay region, in Reports of the Subcommittee for the Tokai District, Coord. Comm. Earthq. Predict., pp. 53-68, Geogr. Surv. Inst., 1977 (in Japanese).

Ishibashi, K., Notes on some destructive earthquakes in the Kanto district that preceded the 1703 great Genroku-Kanto earthquake: 1 . The severe earthquake of 1648 June 12, Zisin (J. Seism. Soc. Jpn.), Second Ser., 31, 342-345, 1978 (in Japanese).

Ishibashi, K., Specification of a soon-to-occur seismic faulting in the Tokai district, central Japan, based upon seismotectonics, in Earthquake Prediction-An International Review, Maurice Ewing Ser. 4, edited by D. W. Simpson and P. G. Richards, pp. 297-332, AGU, Washington, D.C., $1981 \mathrm{a}$.

Ishibashi, K., On the mechanism solution of the 1923 Kanto earthquake, Gekkan Chikyu (The Earth Monthly), 3, 452-454, 1981b (in Japanese).

Ishibashi, K., A practical strategy for earthquake prediction, in Earthquake Prediction Techniques - Their Application in Japan, edited by T. Asada, pp. 249-270, University of Tokyo Press, Tokyo, 1982.

Ishibashi, K., Possibility of a large earthquake near Odawara, central Japan, preceding the Tokai earthquake, Earthq. Predict. Res., 3, 319-344, 1985.

Ishibashi, K., Plate tectonic evolution in the South Fossa Magna (preliminaries), Gekkan Chikyu (The Earth Monthly), 8, 591-597, 1986 (in Japanese).

Ishibashi, K., Problem in the fault model of the 1923 Kanto earthquakeIn special relation to the West-Sagami-Bay fault-, Programme and Abstracts, Seism. Soc. Jpn., 1988 No. 1, 119, 1988a (in Japanese).

Ishibashi, K., "Kanagawa-ken Seibu earthquake" and earthquake prediction I, II, Kagaku, 58, 537-547, 771-780, 1988b, c (in Japanese).

Ishibashi, K., Historical earthquakes near Odawara, central Japan, and their tectonic implications, Chigaku Zasshi (J. Geography), 102, 341-353, 1993 (in Japanese).

Ishibashi, K., Doubt about the tsunami due to the 1782 Ten'mei Odawara, Japan, earthquake: Re-examination of historical documents, Zisin ( $J$. Seism. Soc. Jpn.), Second Ser., 50, 291-302, 1997 (in Japanese with English abstract).

Ishibashi, K., Philippine Sea plate boundary in and around the west part of Sagami Bay, central Japan, Daiyonki Kenkyu (The Quat. Res.), 38, 427434, 1999 (in Japanese with English abstract).

Ishibashi, K., Status of historical seismology in Japan, Annals of Geophysics, 47(2), 2004 (in press).

Ishibashi, K. and M. Ishida, Seismic activity in the South Fossa Magna, central Japan, Modern Geol., 14, 19-33, 1989.
Ishibashi, K. and Y. Itani, Explanation of the westward motion of the Izu Peninsula by collision-An interpretation of GPS velocity vectors-, Zisin (J. Seism. Soc. Jpn.), Second Ser., 56, 387-390, 2004 (in Japanese). Ishibashi, K., Y. Ota, and T. Matsuda, Holocene marine terraces and vertical crustal movement of Hatsu-shima Island in Sagami Bay, central Japan, Zisin (J. Seism. Soc. Jpn.), Second Ser., 35, 195-212, 1982 (in Japanese with English abstract).

Ishida, M., The configuration of the Philippine Sea and the Pacific plates as estimated from the high-resolution microearthquake hypocenters in the Kanto-Tokai district, Japan, Rep. Nat. Res. Center for Disaster Prevention, No. 36, 1-19, 1986 (in Japanese).

Ishida, M., Geometry and relative motion of the Philippine Sea plate and Pacific plate beneath the Kanto-Tokai district, Japan, J. Geophys. Res., 97, 489-513, 1992.

Ishida, M., Seismic activity in the western part of Kanagawa Prefecture, Chigaku Zasshi (J. Geography), 102, 381-392, 1993 (in Japanese).

Ishida, M. and M. Kikuchi, A possible foreshock of a future large earthquake near Odawara, central Japan, Geophys. Res. Lett., 19, 1695-1698, 1992.

Kaizuka, S., Landforms in and around the South Fossa Magna and their tectonic processes of growth, Daiyonki Kenkyu (The Quat. Res.), 23, 5570, 1984 (in Japanese with English abstract).

Kanamori, H., Faulting of the great Kanto earthquake of 1923 as revealed by seismological data, Bull. Earthq. Res. Inst., Univ. Tokyo, 49, 13-18, 1971.

Kasahara, K., On the return period of large earthquakes in the southern Kanto district, Gekkan Chikyu (The Earth Monthly), 7, 440-445, 1985 (in Japanese).

Kato, S., Y. Iwabuchi, A. Asada, Y. Kato, S. Kikuchi, S. Kokuta, K. Kusunoki, and K. Watanabe, Crustal structure and tectonic landform of Sagami Bay, Chigaku Zasshi (J. Geography), 102, 399-406, 1993 (in Japanese).

Kato, S., T. Sato, and M. Sakurai, Multi-channel seismic reflection survey in the Nankai, Suruga and Sagami troughs, Report of Hydrographic Researches, No. 18, 1-23, 1983 (in Japanese with English abstract).

Koyama, M., Reevaluation of the West Sagami Bay Fracture and seismotectonics in and around the northwestern Sagami Bay, Japan, Chigaku Zasshi (J. Geography), 104, 45-68, 1995 (in Japanese with English abstract).

Matsuda, T., Collision of the Izu-Bonin arc with central Honshu: Cenozoic tectonics of the Fossa Magna, Japan, J. Phys. Earth, 26, Suppl., S409S421, 1978.

Matsuda, T., Seismotectonics of the northwestern Sagami Bay area, Chigaku Zasshi (J. Geography), 102, 354-364, 1993 (in Japanese).

Matsu'ura, M., T. Iwasaki, Y. Suzuki, and R. Sato, Statical and dynamical study on faulting mechanism of the 1923 Kanto earthquake, J. Phys. Earth, 28, 119-143, 1980.

Matsu'ura, R. S., M. Nakamura, I. Karakama, and I. Kayano, Reexamination of hypocenters and magnitudes for historical earthquakes-Part 4, Programme and Abstracts, Seism. Soc. Jpn., 2002 Fall Meeting, C66, 2002 (in Japanese).

Nakamura, K. and K. Shimazaki, Sagami and Suruga troughs and subduction of the Philippine Sea plate, Kagaku, 51, 490-498, 1981 (in Japanese).

Nakamura, K., K. Shimazaki, and N. Yonekura, Subduction, bending and eduction: Present and Quaternary tectonics of the northern border of the Philippine Sea plate, Bull. Soc. Geol. France, 26, 221-243, 1984.

Niitsuma, N., Collision tectonics in the South Fossa Magna, central Japan, Modern Geol., 14, 3-18, 1989.

Niitsuma, N., Rupture and delamination of island arc crust due to the arcarc collision in the South Fossa Magna, central Japan, The Island Arc, 8 , 441-458, 1999.

Nishizawa, A., T. Kanazawa, T. Iwasaki, and H. Shimamura, Crustal structure related to the Philippine Sea plate subduction in the northeastern part of the Sagami trough, Japan, Phys. Earth Planet. Inter., 93, 21-36, 1996.

Noguchi, S., Configuration of the Philippine Sea plate and the feature of the seismic activity in the Ibaraki region, Gekkan Chikyu (The Earth Monthly), 7, 97-104, 1985 (in Japanese).

Ohkouchi, N., Active geological structures and tectonics in Sagami Bay area, Chigaku Zasshi (J. Geography), 99, 458-470, 1990 (in Japanese with English abstract).

Ohtake, M., Faulting mode and occurrence probability of the impending western Kanagawa, central Japan earthquake, Chigaku Zasshi (J. Geography), 102, 463-470, 1993 (in Japanese).

Okada, Y., Seismotectonics in the southern Kanto district, central Japan, Zisin (J. Seism. Soc. Jpn.), Second Ser., 43, 153-175, 1990 (in Japanese with English abstract).

Okada, Y., E. Yamamoto, and T. Ohkubo, Coswarm and preswarm crustal deformation in the eastern Izu Peninsula, central Japan, J. Geophys. Res., 
$\mathbf{1 0 5}, 681-692,2000$.

Sakata, S., On the Odawara earthquakes, Bosai Kagaku Gijutsu, Nat. Res. Center for Disaster Prevention, Science and Technology Agency, No. 61, 15-17, 1987 (in Japanese).

Seno, T. and T. Yamasaki, Low-frequency tremors, intraslab and interplate earthquakes in Southwest Japan-from a viewpoint of slab dehydration, Geophys. Res. Lett., 30(22), 2171, doi:10.1029/2003GL018349, 2003.

Seno, T., S. Stein, and A. E. Gripp, A model for the motion of the Philippine Sea plate consistent with NUVEL-1 and geological data, J. Geophys. Res., 98, 17941-17948, 1993.

Seno, T., T. Sakurai, and S. Stein, Can the Okhotsk plate be discriminated from the North American plate?, J. Geophys. Res., 101, 11305-11315, 1996.

Shimazaki, K., K. Nakamura, and N. Yonekura, Suruga trough and Sagami trough - Geodetical and geomorphological movements and plate motion-, Gekkan Chikyu (The Earth Monthly), 3, 455-463, 1981 (in Japanese).

Sugimura, A., Plate boundaries in and around Japan, Kagaku, 42, 192-202, 1972 (in Japanese).

Tada, T., On the Atami-Numazu geotectonic line, Zisin (J. Seism. Soc. Jpn.), Second Ser., 30, 374-377, 1977 (in Japanese).

Takahashi, M., "Collision" tectonics in the South Fossa Magna region as viewed from magma activity, Gekkan Chikyu (The Earth Monthly), 8, 586-591, 1986 (in Japanese).

Takahashi, M., Neogene granitic magmatism in the South Fossa Magna collision zone, central Japan, Modern Geol., 14, 127-143, 1989.

Takeo, M, Rupture process of the 1980 Izu-Hanto-Toho-Oki earthquake deduced from strong motion seismograms, Bull. Seism. Soc. Am., 78, 1074-1091, 1988.

The Research Group for Active Faults of Japan, Active Faults in Japan:
Sheet Maps and Inventories (Revised Edition), 437 pp., University of Tokyo Press, Tokyo, 1991 (in Japanese with English Summary).

Tsuji, Y., On historical earthquakes that attacked Odawara, Gekkan Chikyu (The Earth Monthly), 7, 431-439, 1985 (in Japanese).

Tsuji, Y., Documents of tsunami of the Tenmei Odawara earthquake of August 23, 1782, Zisin (J. Seism. Soc. Jpn.), Second Ser., 39, 277-287, 1986 (in Japanese with English abstract).

Usami, T., Table of historical damaging earthquakes in Japan (English translations of an originally Japanese-language publication, updated to 1995), in Handbook CD \#1 (compiled by M. F. Diggles and W. H. K. Lee) enclosed in International Handbook of Earthquake and Engineering Seismology, Part A, IASPEI (Academic Press), directory/48.4Usami, 2002.

Usami, T., Materials for Comprehensive List of Destructive Earthquakes in Japan [416]-2001 [Latest Edition], 605 pp., University of Tokyo Press, Tokyo, 2003 (in Japanese).

Utsu, T., Recurrence of several earthquakes at almost equal time intervals, Zisin (J. Seism. Soc. Jpn.), Second Ser., 47, 93-95, 1994 (in Japanese).

Wald, D. J. and P. G. Somerville, Variable-slip rupture model of the great 1923 Kanto, Japan, earthquake: Geodetic and body-waveform analysis, Bull. Seism. Soc. Am., 85, 159-177, 1995.

Yoshida, A., Characteristics of seismic activity in the western Kanagawa and their tectonic implications, Zisin (J. Seism. Soc. Jpn.), Second Ser., 43, 205-212, 1990 (in Japanese with English abstract).

Yoshida, A., Seismic activities and tectonics in and around western Kanagawa, Chigaku Zasshi (J. Geography), 102, 407-417, 1993 (in Japanese).

Yoshii, T., Seismic survey experiments in the western Kanagawa Prefecture, Chigaku Zasshi (J. Geography), 102, 393-398, 1993 (in Japanese).

K. Ishibashi (e-mail: ishi@kobe-u.ac.jp) 